\title{
Exploring an integrated curriculum in pharmacy: Educators' perspectives
}

DOI:

10.1016/j.cptl.2017.11.017

\section{Document Version}

Accepted author manuscript

Link to publication record in Manchester Research Explorer

\section{Citation for published version (APA):}

Mawdsley, A., \& Willis, S. (2018). Exploring an integrated curriculum in pharmacy: Educators' perspectives.

Currents in Pharmacy Teaching and Learning. https://doi.org/10.1016/j.cptl.2017.11.017

\section{Published in:}

Currents in Pharmacy Teaching and Learning

\section{Citing this paper}

Please note that where the full-text provided on Manchester Research Explorer is the Author Accepted Manuscript or Proof version this may differ from the final Published version. If citing, it is advised that you check and use the publisher's definitive version.

\section{General rights}

Copyright and moral rights for the publications made accessible in the Research Explorer are retained by the authors and/or other copyright owners and it is a condition of accessing publications that users recognise and abide by the legal requirements associated with these rights.

\section{Takedown policy}

If you believe that this document breaches copyright please refer to the University of Manchester's Takedown Procedures [http://man.ac.uk/04Y6Bo] or contact uml.scholarlycommunications@manchester.ac.uk providing relevant details, so we can investigate your claim.

\section{OPEN ACCESS}




\title{
Manuscript Details
}

\section{Manuscript number}

Title

Article type
CPTL_2016_259

Exploring an integrated curriculum in pharmacy: educators' perspectives

\begin{abstract}
Background and purpose Lack of consensus regarding the benefits of an integrated curriculum, and ambiguity concerning what is being integrated within a pharmacy curriculum exists, but how an integrated curriculum is viewed, epistemologically, and subsequently incorporated into teaching practice has not been investigated. This study explores how educators conceptualize, experience and enact curricula integration both pedagogically and organizationally. Educational activity and setting In-depth qualitative interviews with Faculty members purposively sampled for maximum variation in disciplinary background and teaching experience were undertaken at a single site. Interviews addressed two research questions: how pharmacy educators understand an integrated curriculum and educators' experiences of it. Findings Analysis of the interview data suggests four essential meanings of integration: integration as a method for organizing teaching and learning; integration as enacted by self and others; integration as tension between conflicting knowledge domains; and integration as an impossible concept to apply to teaching practice. Analysis suggests that integration is an abstract rather than enacted concept and although integration is viewed as learner-centered, integration is complex and associated with a loss of in-depth learning. Summary Differences in how Faculty members conceptualize the purpose and effects of integration mean that the level and type of integration reported varied. A clearer understanding of the rationale for change, and methods for better applying theory of integration to teaching practice, may be needed to achieve curriculum standards required by bodies accrediting undergraduate pharmacy programmes.
\end{abstract}

\section{Keywords}

Manuscript region of origin

Corresponding Author

Corresponding Author's

Institution

Order of Authors
Integrated curriculum; curricula change; conceptions of curricula; perspectives on curricula; pharmacy education

\section{Europe}

Andrew Mawdsley

University of Manchester

Andrew Mawdsley, Sarah Willis

\section{Submission Files Included in this PDF}

\section{File Name [File Type]}

CPTL IC Cover Letter CPTL.doc [Cover Letter]

FINAL JULY 2017 Copy Editing Checklist (April 2017).docx [Cover Letter]

FINAL July 2017 CPTL IC responses to reviewer comments revision 1 and 2.docx [Response to Reviewers]

FINAL June 2017 CPTL IC title page .docx [Title Page (with Author Details)]

FINAL July 2017 Integrated (manuscript revised) review 12 and 3.docx [Manuscript (without Author Details)]

FINALv2 June 2017 CPTL IC Table 1 .docx [Table]

FINAL June 2017 CPTL IC Table 2.docx [Table]

To view all the submission files, including those not included in the PDF, click on the manuscript title on your EVISE Homepage, then click 'Download zip file'. 
The University of Manchester

The University of Manchester

School of Health Science

Division of Pharmacy and

Optometry

Stopford Building, Room 1.135

Oxford Road

Manchester M13 9PL

\section{Dear Editor,}

I hope this manuscript finds you well.

Here, we present an evaluation of integrated curricula in UK pharmacy education. Although curricula reform was introduced in 2011 , there has been very little evaluation of the impact of this reform, particularly from the perspective of Faculty.

This paper explores the conceptions and understanding that teachers have for integration, how integration is enacted, how it serves as a point of tension, and the impact this has on the experienced curriculum.

We feel this is of relevance beyond the UK, since many of the Commonwealth countries and North America are using and/or introducing integrated curricula. This study presents important insights in to how Faculty interpret and shape curriculum design and offers insights in to how curricula reform should be approached.

I look forward to hearing from you.

Best wishes,

Andrew Mawdsley

Clinical Lecturer

Clinical Programme Manager (MSc Clinical Pharmacy) 


\section{Currents in Pharmacy Teaching and Learning}

Style and Formatting Checklist

Updated: April 12, 2017

NOTE: This must be completed prior to your final submission. Failure to do so will result in delay in publishing your manuscript.

In addition to any additional revisions offered by the peer reviewers, we also need to get your manuscript ready for production. Your manuscript has not been "accepted" until we have a chance to complete some final copy editing; but for all practical purposes, you have been assigned a volume and issue number as indicated in the message from the Editor-in-Chief. You will use the following as a "checklist" prior to final submission.

\section{Before you begin your formatting:}

Remove all track changes or other editorial comments. Be sure that the function "track changes" has been disabled.

Remove line numbers from manuscript (f they are present). $\checkmark$

Re-identify the manuscript. This entails adding relevant author and/or institutional identifiers, any state/country identifiers, and the names of any other institutions that were removed for peer review purposes. If we have inserted XXX, YYY, ZZZ on your behalf, please remove these placeholders and supply the information that was removed. $\checkmark$

The final manuscript document should have the title of your paper at the top, bold, and centered. Please use sentence case. The word "Abstract" should be below that, full justified, then your abstract, broken down by section headers per your article's type (see below). $\checkmark$

Ensure that the keywords, Conflict of Interest and Disclosure statements are below the abstract. $\checkmark$ Remove the "Evidence of contribution to the literature" statement. That was used exclusively during the peer review process.

\section{Formatting the Manuscript for Production}

Open your manuscript and select all (CTRL+A on PC, Command+A or H+A on Mac). Do all the below actions with all text selected.

a. Set margins to 1" (one inch) all the way around.
b. Change font to Arial 10pt. $\checkmark$
c. Right-click in the document and choose "Paragraph"

i. Change to Full Justification $\checkmark$

ii. Change spacing to Double with Opt before and Opt after paragraphs.

iii. Select the "Tabs" button on the bottom of Paragraph window, and set the default tab to "0.3" --This will then be the default anytime you begin a new paragraph. (Note: this will not adjust all the tabs in the document. You will need to go through and check them) $\checkmark$

d. With Select All still in place, press SHIFT+CTRL+F9 or CTRL +6 on PC (Command +6 or $\mathscr{H}+6$ on Mac) to unlink citations.

i. NOTE: If you have used citation management software, this will unlink those citations. You need to carefully review your citations manually to ensure they are accurate and that they align with your in-text citations. 
Insert page numbers (plain numbers) on the top right. Ensure that they are Arial 10pt font.

Identify the correct section headings for your manuscript type and change as appropriate (NOTE: Your abstract should have IDENTICAL headings to your manuscript. Be sure to format the abstract appropriately).

Commentary

Introduction

Commentary or Perspective

Implications
Experiences in Teaching and Learning (Short Communication)

Background and purpose

Educational activity and setting

Findings

Discussion

Summary
IPE Reports (Short Communication)

Background

Interprofessional education activity

Discussion

\section{Live and Learn (Short Communication)}

Background

Impact

Recommendation(s)

Discussion

\title{
Quality Improvement (Case Report) Teaching and Learning Matters (Case Report) \\ Problem description \\ Quality improvement methods \\ Background \\ Educational activity \\ Results of CQI inquiry \\ Critical analysis of the educational activity
}

Interpretation and discussion

Conclusions

\author{
Research Articles (and Research Notes) \\ Introduction \\ Methods \\ Results \\ Discussion \\ Conclusion
}

\begin{abstract}
Methodology Matters (Review Article)
My (or Our) situation (or issue, problem)

Methodological literature review

My (or Our) recommendations and their applications

Potential Impact
\end{abstract}

Please keep section headings in sentence-case (capitalize only the first word) and bold typeface. You may find it convenient to copy/paste from the table above. Please use italics for your subheadings.

\section{Remove extra spaces.}

a. In CPTL we use only one space after periods. To remove extra spaces:

ii. Press $C T R L+F$ on $P C$ (Command $+F$ or $\mathscr{H}+F$ on Mac) to open the Find window.

iii. Click the drop-down menu to select Find/Replace.

iv. Under "Find" press spacebar twice

v. Under "Replace" press spacebar once

vi. Click "Replace All"

b. Remove all extra line spaces in between paragraphs and sections.

Cite papers by name in-text using the following formatting: $\checkmark$ 
a. Place superscript citation immediately after the reference to the name of the authors when citing a paper by name.

i. Example: "The paper by Smith and Jones ${ }^{7}$ showed a link between student test scores and faculty satisfaction." vs. "The paper by Smith and Jones showed a link between student test scores and faculty satisfaction."

ii. NOTE: Only do this when citing the paper by author name, otherwise place superscript citations at the end of the sentence after punctuation present.

b. Additionally, if you have a multiple-author paper use "Smith et al" vs. "Smith et al." (no period after et al)

REVIEW ALL REFERENCES (line-by-line)

1. Do not rely on citation management software to do this for you.

2. Double-check accuracy of abbreviations, authors names, and completeness. Be sure to include issue numbers along with volume numbers for relevant citations - this is absolutely critical to take care of. Complete page ranges must also be included.

3. For journals, use the NLM title abbreviation, available at: https://www.ncbi.nlm.nih.gov/nlmcatalog/journals. This is what is used in PubMed citations.

4. References to AJPE papers should have a space after the volume and issue number:

a. Example: Fjortoft N, Van Winkle LJ, Hojat M. Measuring empathy in pharmacy students. Am J Pharm Educ. 2011;75(6): Article 109.

5. Do not include DOI numbers following citations.

6. If there is a PubMed citation available, use the formatting except for the month/day and DOI.

a. Example: For the 2013 CAPE Outcomes, the PubMed citation is Am J Pharm Educ. 2013 Oct 14;77(8):162. doi: 10.5688/ajpe778162. Remove the month and day as well as the DOI. The resulting citation would be: Am J Pharm Educ. 2013;77(8): Article 162.

7. Re-access all internet-based citations and put that date as the date accessed. Format internet citations in this manner:

b. Organization. Page Title. Published or Updated Date (month and year preferably). Available at: Complete URL. Accessed Month, Day Year.

i. Example: Gallup Organization. Honesty/Ethics in Professions. Published December 2015. Available at: http://www.gallup.com/poll/1654/honesty-ethicsprofessions.aspx. Acccessed April 12, 2017.

Please replace your references for commonly-cited documents with the following for consistency with journal formatting:

- ACPE Standards 2016:

- Accreditation Council for Pharmacy Education. Accreditation Standards and Key Elements for the Professional Program in Pharmacy Leading to the Doctor of Pharmacy Degree ("Standards 2016"). Published February 2015. Available at: https://www.acpeaccredit.org/pdf/Standards2016FINAL.pdf. Accessed Month Day, Year. (Insert that day's date; the hyperlink will not change).

- ACPE Standards 2016 Guidance Document:

- Accreditation Council for Pharmacy Education. Guidance for the Accreditation Standards and Key Elements for the Professional Program in Pharmacy Leading to the Doctor of Pharmacy Degree ("Guidance for Standards 2016”). Published February 2015. Available at: https://www.acpe-accredit.org/pdf/GuidanceforStandards2016FINAL.pdf. Accessed Month Day, Year (Insert that day's date; the hyperlink will not change).

- CAPE Educational Outcomes 2013:

- Medina MS, Plaza CM, Stowe CD, et al. Center for the advancement of pharmacy education 2013 educational outcomes. Am J Pharm Educ. 2013;77(8): Article 162.

- ACPE Standards 2007 (updated in 2011 to v2.0):

- Accreditation Council for Pharmacy Education. Accreditation Standards and Guidelines for the Professional Program in Pharmacy Leading to the Doctor of Pharmacy Degree 
(“Standards 2007 v2.0"). Published February 2011. Available at: https://www.acpeaccredit.org/pdf/FinalS2007Guidelines2.0.pdf. Accessed Month Day, Year (Insert that day's date; the hyperlink will not change).

Properly format numbers.

a. When a number is describing a quantity (such as \# of apples), spell out numbers below 10 (i.e., "one" instead of "1") and use numerals for anything 10 or above.

b. When a number is part of a title or a descriptor (such as Exam 2), numerals are appropriate.

c. Always spell out numbers that are the first word of a sentence.

Be sure that $A L L$ abbreviations are spelled out the first time they are used. Pay careful attention to the introduction section. This includes commonly used abbreviations such as GPA, APPE, etc.

Include acknowledgments section at the end of the paper just before the References (if relevant).

Check for all instances of "our institution" or equivalent terminology and replace with the correct identification.

Provide complete and accurate contact information for ALL authors on the title page.

The title page has been specifically formatted by the editor - please DO NOT change the format of the title page as it is currently uploaded. You can certainly change the content of the title page - especially if author contact information has changed. Be sure that the abstract on the title page is the same as that found on the first page of the manuscript. $\checkmark$

\section{Make sure that the abstract is $\mathbf{2 5 0}$ words or less.}

\section{Complete tables and figures.}

a. Upload each revised table/figure as a separate document in its original format (not fdf or pdf formats).

b. Define each abbreviation used in the appropriate table/figure legend.

Once we review your revised manuscript and conduct appropriate copy editing your manuscript will be slated into an issue.

Please make sure that all of these items are addressed thoroughly. We will return your manuscript to you if we identify any that have not been completely addressed. We are trying hard to make sure that you have few if any corrections to make on your proof copies. This in turn will speed production to the online "article in press" stage.

Manuscript Number: CPTL_2016_259_R2

Date: $02 / 08 / 2017$ 
5

Printed Name: Andrew Mawdsley

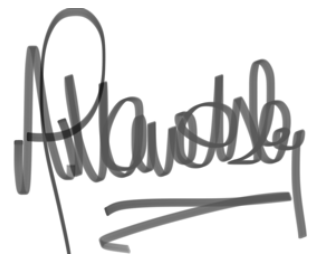


Ref: CPTL_2016_259

Title: Exploring an integrated curriculum in pharmacy: educators' perspectives

Journal: Currents in Pharmacy Teaching and Learning

July 2017, in-house reviewer comments:

We thank you again for your thorough and balanced review. We hope we have addressed these final comments below. Thank you for considering our work in the Journal, and for the process of review which has strengthened our work considerably.

\section{A few specific comments:}

-Table 1 could be easier to read and compare if check boxes were used for each participant (columns for each identifier like Scientist/Pharmacist or Leader/Non-leader, etc.). The table has been reformatted and check boxes are now used to display the characteristics of the participants.

-While Reviewer 2 was adamant about the need to discuss assessment, I don't feel it is the focus of the paper and agree with the authors that it does not have to be included. While it would be nice to talk about, it is not necessary and was not mentioned by participants. But it could not hurt for the authors to add a section about what they plan to investigate next. We have added a brief section which details further research - considering student perspectives of integration on learning and assessment.

There is some work that we need for you to do in order to decrease the time to publication. I will send you the copy editing checklist that you will need to complete via email.

Completed and submitted.

We anticipate including your manuscript in CPTL Volume 10 Issue 3.

\begin{tabular}{|l|l|l|l|}
\hline Reviewers comments & Author responses & Reviewers comments & Author responses \\
\hline Editors comments & \multicolumn{3}{|l|}{} \\
\hline $\begin{array}{l}\text { Thanks for your patience while your } \\
\text { completed reviews were submitted }\end{array}$ & $\begin{array}{l}\text { The authors would like to thank the } \\
\text { Editor, and the three reviewers, for }\end{array}$ & $\begin{array}{l}\text { Thanks for your patience while } \\
\text { your completed reviews were }\end{array}$ & $\begin{array}{l}\text { The authors apologise for not } \\
\text { responding to the reviewers' }\end{array}$ \\
\hline
\end{tabular}




\begin{tabular}{|c|c|c|c|}
\hline $\begin{array}{l}\text { and I had an opportunity to review } \\
\text { the comments provided. Your } \\
\text { reviewers offered publication } \\
\text { recommendations (minor revision; } \\
\text { major revision x2) that indicate that } \\
\text { there is a bit of work to be done prior } \\
\text { to acceptance. Your reviewers } \\
\text { offered a constructive and thorough } \\
\text { set of recommendations that look to } \\
\text { add clarity in some sections, to fix } \\
\text { several inaccuracies, and to provide } \\
\text { a bit of organization in other } \\
\text { sections. There is concern that your } \\
\text { conclusions cannot be derived from } \\
\text { the work performed. There is } \\
\text { concern that your attribution to } \\
\text { phenomenology may not be wholly } \\
\text { accurate. I encourage you to } \\
\text { carefully read the recommendations } \\
\text { offered to you and revise your } \\
\text { manuscript accordingly. Please } \\
\text { maintain your manuscript in a de- } \\
\text { identified format so that a second } \\
\text { peer review can be conducted. }\end{array}$ & $\begin{array}{l}\text { their timely and careful } \\
\text { consideration of the manuscript. The } \\
\text { reviewers have offered interesting } \\
\text { perspectives on the work which } \\
\text { have been addressed as outlined } \\
\text { below. } \\
\text { We note the concern that the } \\
\text { conclusions cannot be derived from } \\
\text { the work and have sought to } \\
\text { strengthen the arguments made in } \\
\text { the paper, and to include further } \\
\text { detail about our approach. } \\
\text { However, the manuscript has been } \\
\text { submitted as a Short } \\
\text { Communication (Experiences in } \\
\text { Teaching and Learning) rather than } \\
\text { as a research paper and this } \\
\text { restricts the detail that can be } \\
\text { included. }\end{array}$ & $\begin{array}{l}\text { submitted and I had an } \\
\text { opportunity to review the } \\
\text { comments. Your reviewers } \\
\text { offered publication } \\
\text { recommendations (accept x2, } \\
\text { minor revisions) that are } \\
\text { generous. There are factual } \\
\text { flaws in your manuscript and } \\
\text { other issues that have been } \\
\text { very generously addressed by } \\
\text { at least two of your reviewers. } \\
\text { It is of grave concern that you } \\
\text { adopted the attitude that you } \\
\text { have with this peer review } \\
\text { process. We value our peer } \\
\text { reviewers and their time and } \\
\text { rely on them to offer quality } \\
\text { guidance and coaching, which } \\
\text { they have. I will spare these } \\
\text { reviewers the need to provide a } \\
\text { third and final peer review and } \\
\text { instead will have our qualitative } \\
\text { research-based Editorial Board } \\
\text { members review your revised } \\
\text { manuscript. If our in-house } \\
\text { folks agree that you have } \\
\text { addressed the } \\
\text { recommendations of the } \\
\text { original reviewers and that your } \\
\text { manuscript is suitable for } \\
\text { publication, then we will } \\
\text { proceed into production. } \\
\text { in order to move your } \\
\text { manuscript into production, }\end{array}$ & $\begin{array}{l}\text { comments in a way that } \\
\text { addressed their questions and } \\
\text { for not making the requested } \\
\text { revisions. Our intention was not } \\
\text { to disregard, or ignore these; } \\
\text { they were constructive and } \\
\text { thorough and have } \\
\text { undoubtedly improved the } \\
\text { paper. Rather, we made every } \\
\text { attempt to address all the } \\
\text { reviewers' comments when } \\
\text { making changes to the } \\
\text { manuscript. If we did not, then } \\
\text { this was down to our } \\
\text { misunderstanding of the } \\
\text { revisions requested and we did } \\
\text { not intend for this to come } \\
\text { across as arrogance or } \\
\text { disregard for the peer review } \\
\text { process. } \\
\text { We would like to thank the } \\
\text { Editor and reviewers for their } \\
\text { time and generous reviews of } \\
\text { the work and we absolutely } \\
\text { agree that the work is better as } \\
\text { a result of the thorough review. }\end{array}$ \\
\hline
\end{tabular}




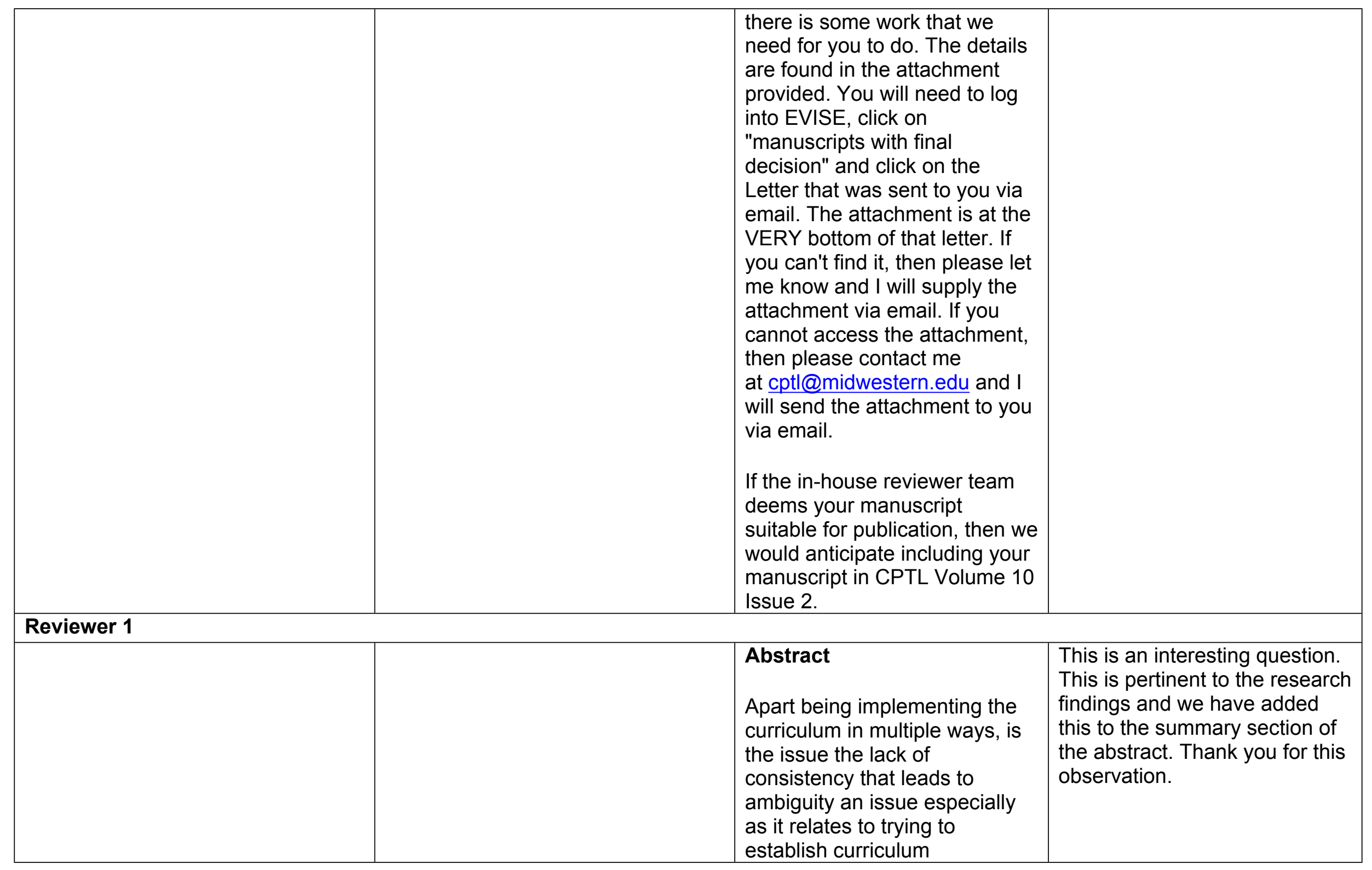




\begin{tabular}{|c|c|c|c|}
\hline & & standards? & \\
\hline & & $\begin{array}{l}\text { I do not understand "enact } \\
\text { paradigm shift". What does this } \\
\text { relate to? }\end{array}$ & $\begin{array}{l}\text { Wording has been edited for } \\
\text { clarity. }\end{array}$ \\
\hline $\begin{array}{l}\text { Introduction Sections } \\
\text { Page } 3,4^{\text {th }} \text { line about second } \\
\text { paragraph. Sentence that includes } \\
\text { "modest feelings". This phrasing is } \\
\text { awkward and unclear. I believe the } \\
\text { authors are discussing modest gains } \\
\text { / differences. If I am correct, this } \\
\text { needs to be rephrased such that it } \\
\text { reflects the statistical meaning }\end{array}$ & $\begin{array}{l}\text { This sentence has been rewritten to } \\
\text { reflect the conclusive meaning } \\
\text { described in the literature. } \\
\text { "There is also some evidence that } \\
\text { graduates of an integrated } \\
\text { curriculum have modest feelings } \\
\text { about being better prepared than } \\
\text { those from a traditional modular } \\
\text { programme" now reads "It has been } \\
\text { demonstrated that integration } \\
\text { trivializes difficult concepts, sidelines } \\
\text { aspects of understanding, can be } \\
\text { unachievable for teachers, learners } \\
\text { and institutions, and has little or no } \\
\text { impact on learning outcomes, with a } \\
\text { study comparing graduates of an } \\
\text { integrated and modular pharmacy } \\
\text { curriculum finding little difference in } \\
\text { terms of preparation for practice". }\end{array}$ & $\begin{array}{l}\text { Introduction } \\
\text { General comment: many long } \\
\text { sentences ( } 3 \text { to } 5 \text { lines long) } \\
\text { that sometimes result in } \\
\text { unclear messaging. Consider } \\
\text { simplifying and breaking some } \\
\text { up to ensure the transmission } \\
\text { of a clear idea/concept. }\end{array}$ & $\begin{array}{l}\text { We agree that the introduction, } \\
\text { and certain areas throughout, } \\
\text { needed to be edited for ease of } \\
\text { reading. Changes have been } \\
\text { made to the document which } \\
\text { we hope will improve } \\
\text { readability. }\end{array}$ \\
\hline $\begin{array}{l}\text { Pages 3-4: Approaches to } \\
\text { Integration } \\
\text { Are the two approaches presented } \\
\text { are as a result of a general } \\
\text { consensus from the available body } \\
\text { of literature or are they examples of } \\
\text { two approaches presented in one } \\
\text { specific article / reading? Also, } \\
\text { clearer distinction between the two } \\
\text { could be made. Again, I understand }\end{array}$ & $\begin{array}{l}\text { Here, the authors are explaining } \\
\text { how the integration ladder (Harden, } \\
2000 \text { ) has been picked up as a } \\
\text { model for promoting certain levels } \\
\text { and types of integration, yet the } \\
\text { level of integration being promoted } \\
\text { is likely to be unattainable and } \\
\text { contradicts findings from the } \\
\text { literature on integration. This section } \\
\text { has been redeveloped with } \\
\text { additional background material }\end{array}$ & $\begin{array}{l}\text { Page 3: Lines } 54-57 \text { : } \\
\text { sentence in unclear and } \\
\text { somewhat paradoxical. }\end{array}$ & $\begin{array}{l}\text { Unfortunately, the line numbers } \\
\text { of the reviewers copy and our } \\
\text { copy (downloaded from the } \\
\text { files section of the submission } \\
\text { site) do not match. We think we } \\
\text { have located the unclear } \\
\text { statement and edited for clarity. }\end{array}$ \\
\hline
\end{tabular}




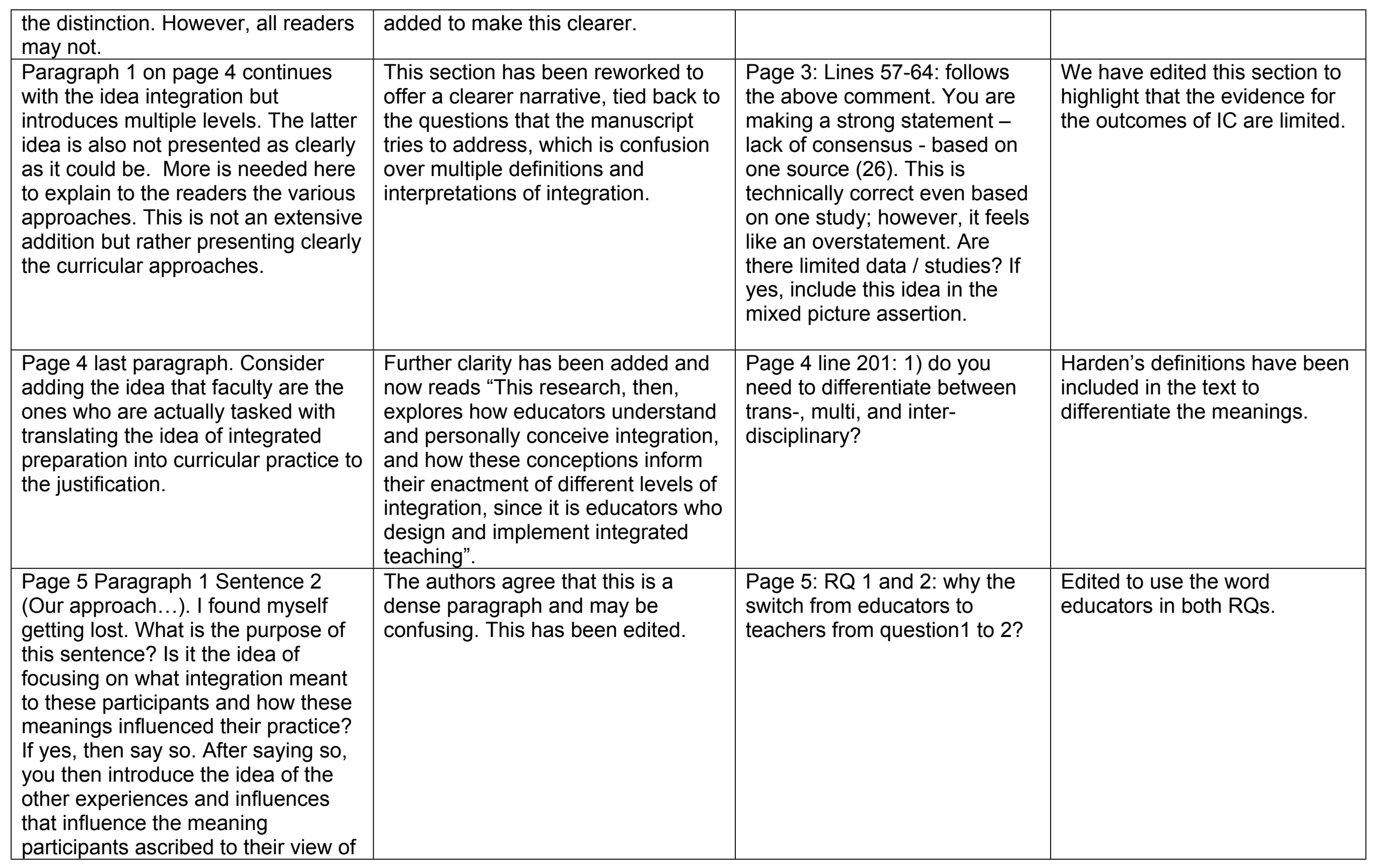




\begin{tabular}{|c|c|c|c|}
\hline $\begin{array}{l}\text { and approach to integration. The } \\
\text { ideas are present - the delivery } \\
\text { needs some tweaking. }\end{array}$ & & & \\
\hline $\begin{array}{l}\text { Sentence } 5 \text { (number of interviews). } \\
\text { Do you mean number of participants } \\
\text { or number of interviews? This was } \\
\text { unclear when read initially because I } \\
\text { did not connect the number of } \\
\text { interviews to mean the number of } \\
\text { participants. }\end{array}$ & This ambiguity has been clarified. & & \\
\hline $\begin{array}{l}\text { General question: Is the idea } \\
\text { integration also influenced by the } \\
\text { Interprofessional education } \\
\text { movement and the possible links to } \\
\text { improved patient outcomes? If yes, } \\
\text { this is not clearly articulated } \\
\text { anywhere. }\end{array}$ & $\begin{array}{l}\text { This is an interesting question, but } \\
\text { not one which has been explored } \\
\text { within this study. Here, we are } \\
\text { exploring integration within a } \\
\text { curriculum and not integration } \\
\text { across the professions. }\end{array}$ & & \\
\hline $\begin{array}{l}\text { Methods Section } \\
\# 1 \text { : Methodological Issues: The } \\
\text { abstract included more } \\
\text { methodological information than the } \\
\text { actual methods section }\end{array}$ & $\begin{array}{l}\text { The educational activity and setting } \\
\text { section has been edited and } \\
\text { expanded. }\end{array}$ & Page 6 line 14: variables? & Removed. \\
\hline $\begin{array}{l}\text { 1a) Methods: No "role of } \\
\text { researchers" in the methods section. }\end{array}$ & Details have now been added. & $\begin{array}{l}\text { Comment: Did you mention the } \\
\text { length and general conditions } \\
\text { of the interviews? }\end{array}$ & $\begin{array}{l}\text { We have added these details to } \\
\text { the section. }\end{array}$ \\
\hline $\begin{array}{l}\text { 1b) Methods: The abstract } \\
\text { mentioned maximum variation } \\
\text { purposeful sampling - yet no } \\
\text { mention in the methods section. } \\
\text { This needs to be connected to how } \\
\text { the final } 8 \text { were chosen. The readers } \\
\text { need to know who the participants } \\
\text { are, why they were chosen, and how }\end{array}$ & $\begin{array}{l}\text { We have provided further rationale } \\
\text { of the sampling method. }\end{array}$ & $\begin{array}{l}\text { Comment / questions related to } \\
\text { your sample. You mentioned } \\
\text { maximum variation in terms of } \\
\text { background and rank (grade). I } \\
\text { noticed each participant is a } \\
\text { lecturer, which is traditionally a } \\
\text { teaching faculty rank. If I am } \\
\text { correct, I do not think there is }\end{array}$ & $\begin{array}{l}\text { Our sample included } \\
\text { participants from different } \\
\text { grades and roles, rather than } \\
\text { simply sampling lecturers. We } \\
\text { apologise if we have caused } \\
\text { confusion here; we have } \\
\text { updated Table } 1 \text { to better } \\
\text { demonstrate the variation in } \\
\end{array}$ \\
\hline
\end{tabular}




\begin{tabular}{|c|c|c|c|}
\hline $\begin{array}{l}\text { each contributed to understanding } \\
\text { the phenomenon being examined. }\end{array}$ & & $\begin{array}{l}\text { variation here except maybe in } \\
\text { terms of rank within lecturer } \\
\text { appointments including the } \\
\text { factors that influence being a } \\
\text { senior lecturer vs. not. Also, if I } \\
\text { am correct, I suggest you do } \\
\text { the following: 1) address this } \\
\text { rank issue in the section where } \\
\text { you describe your participants } \\
\text { and sampling method; } 2 \text { ) } \\
\text { include the factors that result in } \\
\text { different ranks if these factors } \\
\text { germane to the maximum } \\
\text { variation strategy; and } 3 \text { ) } \\
\text { discuss how sampling lecturers } \\
\text { is appropriate in terms of } \\
\text { curriculum and teaching } \\
\text { responsibility and thus fits } \\
\text { within purposeful sampling. }\end{array}$ & $\begin{array}{l}\text { grade and role of those taking } \\
\text { part in the study. We have also } \\
\text { included further text describing } \\
\text { differences in rank and role to } \\
\text { illustrate the variation within the } \\
\text { sample. } \\
\text { We also purposively sampled } \\
\text { participants according to their } \\
\text { role in curriculum design, } \\
\text { teaching or teaching and } \\
\text { research contract and } \\
\text { leadership role as based on the } \\
\text { literature and our experiences } \\
\text { as pharmacy educators we } \\
\text { thought it was important to } \\
\text { capture the range of } \\
\text { perspectives based on these } \\
\text { characteristics. We have } \\
\text { provided further description } \\
\text { and rationale for our purposive } \\
\text { sampling in the manuscript and } \\
\text { further information has been } \\
\text { included in Table } 1 .\end{array}$ \\
\hline $\begin{array}{l}\text { 1c) Methods: Very little on analysis } \\
\text { approach - again more mentioned } \\
\text { in the abstract and yet little to } \\
\text { nothing in the methods section. }\end{array}$ & \multirow[t]{2}{*}{$\begin{array}{l}\text { Further clarity has been provided } \\
\text { about the analysis of the data. } \\
\text { Transferability has been further } \\
\text { addressed in the discussion. }\end{array}$} & & \\
\hline $\begin{array}{l}\text { 1d) Methods: addressing quality } \\
\text { (credibility, transferability, } \\
\text { believability, etc.): no mention of this } \\
\text { by the authors. Triangulation and } \\
\text { other strategies used? If not - they } \\
\text { should. If they did, these need to be }\end{array}$ & & & \\
\hline
\end{tabular}




\begin{tabular}{|c|c|c|c|}
\hline $\begin{array}{l}\text { discussed in both methods and } \\
\text { findings as appropriate. }\end{array}$ & & & \\
\hline $\begin{array}{l}\text { 1e) Methods: central question, sub- } \\
\text { questions, interview questions: } \\
\text { There is a lack of congruency } \\
\text { among and between these } \\
\text { components. The authors identified } \\
\text { two general questions. However, } \\
\text { what is the overarching / going } \\
\text { question and how is it connected to } \\
\text { the phenomenon being studied? } \\
\text { The authors also mentioned pilot } \\
\text { questions. They are not established } \\
\text { that these two questions were } \\
\text { enough to connect the data } \\
\text { collection to the larger research } \\
\text { question. I understand the need for } \\
\text { dialog and rich data. However, your } \\
\text { questions connect the varied } \\
\text { participants and therefore must have } \\
\text { structure leaded to the inquiry. }\end{array}$ & $\begin{array}{l}\text { There are two main research } \\
\text { questions investigated in this study } \\
\text { - now added to the manuscript. } \\
\text { These questions were } \\
\text { operationalised in the research by } \\
\text { asking two broad questions; what is } \\
\text { an integrated curriculum and also } \\
\text { how is integration achieved in your } \\
\text { teaching? Each interview was a } \\
\text { dialogue around these questions. } \\
\text { It would be difficult to provide a full } \\
\text { account of the technicalities of the } \\
\text { interview due to the Journal } \\
\text { restrictions and requirements - short } \\
\text { communication, not research paper. }\end{array}$ & & \\
\hline $\begin{array}{l}\text { Findings Section } \\
\text { Comment Only: As I read the } \\
\text { findings and given what stated in } \\
\text { background sections (lack of } \\
\text { consensus on what integration } \\
\text { meant), I wondered whether the } \\
\text { authors should consider including a } \\
\text { grounded theory approach to } \\
\text { present their findings. Grounded } \\
\text { Theory is appropriate when there is } \\
\text { a lack of theory and as such, the } \\
\text { use of this method fit within the } \\
\text { larger scope of this study's purpose. }\end{array}$ & $\begin{array}{l}\text { This is a very interesting point and } \\
\text { we will consider this as we further } \\
\text { investigate issues around } \\
\text { integration and the student } \\
\text { perspective/impact on learning. }\end{array}$ & $\begin{array}{l}\text { Findings } \\
\text { Page 7, meaning \#2: A } \\
\text { suggestion for consistency / } \\
\text { parallelism: "Integration as } \\
\text { enacted by self and others } \\
\text { (practice). I think this will fit } \\
\text { within your RQs. }\end{array}$ & Thank-you, edited. \\
\hline
\end{tabular}




\begin{tabular}{|c|c|c|c|}
\hline $\begin{array}{l}\text { Just thought. The authors may also } \\
\text { consider a Grounded Theory } \\
\text { approach in a separate manuscript } \\
\text { related this work. Again, just a } \\
\text { thought. }\end{array}$ & & & \\
\hline $\begin{array}{l}\text { General Comment: the layout and } \\
\text { presentation of the contents of the } \\
\text { manuscript are hindering the flow. } \\
\text { This is especially so in the findings. }\end{array}$ & $\begin{array}{l}\text { The paper has used the Journal } \\
\text { layout requirements to structure the } \\
\text { manuscript. }\end{array}$ & $\begin{array}{l}\text { Page } 8 \text {, line } 450 \text { : is it recognize } \\
\text { "and agree"? }\end{array}$ & Edited, thanks. \\
\hline $\begin{array}{l}\text { 2a) Research question. Lack of } \\
\text { clarity continues to be problematic. } \\
\text { This issue is related to the Methods } \\
\text { section. }\end{array}$ & $\begin{array}{l}\text { The research questions are now } \\
\text { included within the manuscript - see } \\
\text { details in previous comments above. }\end{array}$ & & \\
\hline $\begin{array}{l}\text { 2b) Participants were not described. } \\
\text { This is an issue especially given the } \\
\text { idea of maximum variation. What } \\
\text { are their backgrounds especially as } \\
\text { related to the inquiry? What points } \\
\text { of view are the beliefs and } \\
\text { experiences representing? This is } \\
\text { necessary to understanding what } \\
\text { integration means and the } \\
\text { understanding of the curriculum. }\end{array}$ & $\begin{array}{l}\text { See details in previous comments } \\
\text { above. }\end{array}$ & & \\
\hline $\begin{array}{l}\text { 2c) Were the themes influenced in } \\
\text { any way a priori coding / } \\
\text { expectations? Again, related to } \\
\text { methods. }\end{array}$ & $\begin{array}{l}\text { No. The themes were generated } \\
\text { through the analysis of the data. }\end{array}$ & & \\
\hline $\begin{array}{l}\text { 2d) Your findings section should } \\
\text { match the four themes presented on } \\
\text { page } 6 . \text { For example, "Integration as } \\
\text { method" vs. "integration as a } \\
\text { method and structure for curriculum } \\
\text { design" are two very different things. } \\
\text { You should also consider using the } \\
\text { research questions as part of the }\end{array}$ & $\begin{array}{l}\text { The four themes are now used as } \\
\text { heading titles for continuity. }\end{array}$ & & \\
\hline
\end{tabular}




\begin{tabular}{|c|c|c|c|}
\hline organizing structure. & & & \\
\hline $\begin{array}{l}\text { 2e) Integration as a method and } \\
\text { structure for curriculum design } \\
\text { section. } \\
\text { 2ei: it may be useful to tell us two } \\
\text { the "pharmacy regulators" are -. Are } \\
\text { they not colleagues from within the } \\
\text { profession? As presented, they } \\
\text { sound very foreign to the current } \\
\text { issue. } \\
\text { 2eii: Comment: Sounds like they } \\
\text { are not actually integrating... Is this } \\
\text { important to your findings? }\end{array}$ & $\begin{array}{l}\text { 2ei. Edited to GPhC. A tension } \\
\text { exists; the GPhC regulate and } \\
\text { accredit the MPharm programme, so } \\
\text { in many respects, the organisation is } \\
\text { detached from individual schools. } \\
\text { The discussion discusses how the } \\
\text { data describes integration situated } \\
\text { at the correlation level as described } \\
\text { by Harden. }\end{array}$ & $\begin{array}{l}\text { Page } 10 \text { line } 563: \text { who is the } \\
\text { they in “... they don't have } \\
\text { enough...? Is it the student or } \\
\text { the faculty member? }\end{array}$ & $\begin{array}{l}\text { This comment was about } \\
\text { students - and has now been } \\
\text { edited for clarity. }\end{array}$ \\
\hline $\begin{array}{l}\text { 2f) Enacting } \\
\text { 2fi: Where do feelings of confusion } \\
\text { and anxiety fit within the findings? } \\
\text { How much is this related to the } \\
\text { conflict of identity: scientist vs. } \\
\text { teacher; the self vs. the greater } \\
\text { good almost; loss of status as a } \\
\text { scientist; revelations / exposure of } \\
\text { personal limitations (comment that } \\
\text { scientist "are not daft"); etc.? This } \\
\text { idea (these ideas), in my opinion, } \\
\text { permeates and they have not been } \\
\text { addressed adequately, especially } \\
\text { with the idea of variations among } \\
\text { participants... There are some } \\
\text { echoes of addressing these } \\
\text { thoughts in the "What is stopping } \\
\text { integration from happening" section. }\end{array}$ & $\begin{array}{l}\text { Further clarity of this point has been } \\
\text { added in this section "what is } \\
\text { stopping integration", relating these } \\
\text { findings around anxiety of identity to } \\
\text { the impact on integration. }\end{array}$ & $\begin{array}{l}\text { Comments / general questions } \\
\text { about Integration as tension: 1) } \\
\text { are your participants' } \\
\text { comments reflections of their } \\
\text { own fears and beliefs? 2) Is the } \\
\text { GphC's requirements of } \\
\text { integration not addressing } \\
\text { important sub-systems } \\
\text { (elements) required for } \\
\text { integration? Again, these are } \\
\text { not editorial - merely thoughts I } \\
\text { had as I read. My second } \\
\text { question ties into your findings } \\
\text { in "Integration as Impossible". }\end{array}$ & $\begin{array}{l}\text { Yes, we do believe that this is } \\
\text { the surfacing of personal } \\
\text { fears/beliefs - we have added } \\
\text { a line to highlight this more. } \\
\text { We also agree with your } \\
\text { observation that the GPhC's } \\
\text { requirement for integration is } \\
\text { indeed surfaced in grass-roots } \\
\text { tensions. We hope that this } \\
\text { idea is picked up in the } \\
\text { discussion. }\end{array}$ \\
\hline Final Comment: I am at the end. Did & The authors hope that through & Page 11 first paragraph under & Thank you. Additional \\
\hline
\end{tabular}




\begin{tabular}{|c|c|c|c|}
\hline $\begin{array}{l}\text { the authors answer their research } \\
\text { question(s) and achieved their } \\
\text { research purpose? Not convincingly. }\end{array}$ & $\begin{array}{l}\text { addressing the comments above the } \\
\text { reviewer is more easily able to } \\
\text { connect the findings and discussion } \\
\text { back to the original aim and } \\
\text { research questions; meaning of } \\
\text { integration and experience of } \\
\text { integration. }\end{array}$ & $\begin{array}{l}\text { Discussion. I would also say } \\
\text { that participants' experiences } \\
\text { though not generalizable, } \\
\text { provides some potentially key } \\
\text { insights into barriers to reform, } \\
\text { which must be addressed - } \\
\text { especially given the faculty role } \\
\text { in the process. You do mention } \\
\text { the idea of transferability. } \\
\text { However, I think the point } \\
\text { should be reinforced. If this is } \\
\text { wide-spread enough, then } \\
\text { reform will not happen as } \\
\text { intended - if at all. }\end{array}$ & $\begin{array}{l}\text { sentences have been added to } \\
\text { this section which strengthens } \\
\text { our stance on transferability of } \\
\text { the research findings. We have } \\
\text { edited to include this comment. } \\
\text { We are pleased that the } \\
\text { reviewer recongises the } \\
\text { relevance of the study beyond } \\
\text { our own institution. }\end{array}$ \\
\hline & & $\begin{array}{l}\text { Question: what integration } \\
\text { model (if any) is occurring, } \\
\text { trans-, multi, and inter- } \\
\text { disciplinary? You introduced } \\
\text { the three approaches in the } \\
\text { introduction and mentioned } 2 \\
\text { on page } 13 \text { line } 741 \text {. How do } \\
\text { your results fit? }\end{array}$ & $\begin{array}{l}\text { We think we have addressed } \\
\text { this question in the discussion } \\
\text { and have tried to make this } \\
\text { clearer in the revised } \\
\text { manscript. Under "How is } \\
\text { integration enacted" we } \\
\text { conclude that the integration } \\
\text { level at this site is correlation } \\
\text { "the emphasis remains on the } \\
\text { disciplines or subjects with } \\
\text { subject-based courses taking up } \\
\text { most of the curriculum time. Within } \\
\text { this framework, an integrated } \\
\text { teaching session is introduced in } \\
\text { addition to the subject-based } \\
\text { teaching. This session brings } \\
\text { together areas of interest common } \\
\text { to each of the subjects". }\end{array}$ \\
\hline \multicolumn{4}{|l|}{ Reviewer 2} \\
\hline General & $\begin{array}{l}\text { The research explores participants' } \\
\text { meanings of integration, as seen }\end{array}$ & $\begin{array}{l}\text { - Thanks for your responses } \\
\text { to the review previously }\end{array}$ & $\begin{array}{l}\text { We take peer-review very } \\
\text { seriously, and always feel our }\end{array}$ \\
\hline
\end{tabular}




\begin{tabular}{|c|c|c|c|}
\hline $\begin{array}{l}\text { I am not convinced this in a } \\
\text { phenomenology, it is not a } \\
\text { description of experiences leading to } \\
\text { a summary which condenses that } \\
\text { experience into a paragraph. This is } \\
\text { a set of views based upon } \\
\text { experience within a curriculum. If } \\
\text { one were to argue this is a, } \\
\text { interpretive phenomenological } \\
\text { analysis even then I do not see a } \\
\text { series of experiences being relayed, } \\
\text { these are views and in some cases } \\
\text { quite entrenched views with little } \\
\text { evidence to support them. I would } \\
\text { argue this would work within a } \\
\text { modified grounded theory approach } \\
\text { if reworked or simply a case study } \\
\text { approach but it is not a } \\
\text { phenomenology in my opinion. }\end{array}$ & $\begin{array}{l}\text { through their reality of it, tied to their } \\
\text { personal experiences of integration. } \\
\text { The views are analysed and } \\
\text { interpreted to conclude how the } \\
\text { participants understand the } \\
\text { phenomenon as experienced at this } \\
\text { site. }\end{array}$ & $\begin{array}{l}\text { submitted for your paper. In my } \\
\text { opinion there remain some } \\
\text { issues with this work that will } \\
\text { need to be properly thought } \\
\text { through before it could be } \\
\text { accepted in the journal. I would } \\
\text { suggest that the authors note } \\
\text { that asserting their view does } \\
\text { not necessarily make it correct, } \\
\text { reviewers give their time freely } \\
\text { and the tone in this response is } \\
\text { disappointing and lack } \\
\text { reflection, I would recommend } \\
\text { the authors consider this in } \\
\text { future when responding to peer } \\
\text { reviewers. Peer review is a } \\
\text { process designed to improve } \\
\text { submissions and in my } \\
\text { experience my work is always } \\
\text { improved after I receive } \\
\text { reviews from colleagues. } \\
\text { 1. I remain unconvinced this is } \\
\text { a phenomenology, this method } \\
\text { clearly requires participants to } \\
\text { discuss their experiences of a } \\
\text { phenomenon and not simply } \\
\text { give their views. I cannot see } \\
\text { discussion of experiences here } \\
\text { and in many cases the views } \\
\text { being expressed pre-date the } \\
\text { experience. The methodology } \\
\text { has a clear set of literature } \\
\text { based on the work of Husserl } \\
\text { and Heidegger amongst others. }\end{array}$ & $\begin{array}{l}\text { papers are better for the } \\
\text { process. We appreciate highly } \\
\text { the level of detail and } \\
\text { comments provided by all the } \\
\text { reviewers and the paper is very } \\
\text { much strengthened as a result. } \\
\text { We apologise if this reviewer } \\
\text { felt we had ignored their } \\
\text { detailed comments or if it } \\
\text { seems that we had not } \\
\text { addressed them in our } \\
\text { resubmitted manuscript. It was } \\
\text { not our intention to disappoint } \\
\text { the reviewer. }\end{array}$ \\
\hline
\end{tabular}




\begin{tabular}{|c|c|c|c|}
\hline & & $\begin{array}{l}\text { In my view this should be } \\
\text { reviewed and I would not } \\
\text { accept this paper as it is } \\
\text { currently framed, given what I } \\
\text { see as clear issues around this } \\
\text { method as a particular choice. } \\
\text { In my previous review I } \\
\text { suggested modified grounded } \\
\text { theory as a framework. Whilst } \\
\text { this isn't great in terms of being } \\
\text { post-hoc theoretical framing I } \\
\text { would argue it is better than } \\
\text { where it is at present. }\end{array}$ & $\begin{array}{l}\text { agree that the description of } \\
\text { our approach as an interpretive } \\
\text { case-study is a much more } \\
\text { accurate and methodologically } \\
\text { consistent with how we } \\
\text { designed and conducted the } \\
\text { study. The study adopted an } \\
\text { inductive, contextual approach } \\
\text { to understanding integration, } \\
\text { and although we did not set } \\
\text { out, a priori, to theorise or to } \\
\text { use a grounded theory } \\
\text { approach a modified grounded } \\
\text { theory approach does seem a } \\
\text { better way to describe it. The } \\
\text { authors are grateful to the } \\
\text { reviewer in helping us with this } \\
\text { question. }\end{array}$ \\
\hline
\end{tabular}




\begin{tabular}{|c|c|c|c|}
\hline & integration. & $\begin{array}{l}\text { curricula are really only } \\
\text { effective if they provide } \\
\text { stimulus for students to learn in } \\
\text { an integrative manner then } \\
\text { assessment is absolutely } \\
\text { central to that argument. }\end{array}$ & $\begin{array}{l}\text { questions explored in this study } \\
\text { educators' descriptions of their } \\
\text { experiences of enacting } \\
\text { integrated teaching did not tend } \\
\text { to draw on how they designed } \\
\text { integrated assessments or } \\
\text { difficulties in doing this. Prior } \\
\text { to starting the data collection } \\
\text { we anticipated that assessment } \\
\text { would have been discussed, } \\
\text { but it was not. } \\
\text { Future research could } \\
\text { investigate this further. } \\
\text { We are currently undertaking a } \\
\text { study of students' views of } \\
\text { integration and it is a very } \\
\text { important central theme to their } \\
\text { understanding of integration, } \\
\text { which is an interesting } \\
\text { distinction. }\end{array}$ \\
\hline $\begin{array}{l}\text { Abstract } \\
\text { Adopting should have a lower case } \\
\text { A, first paragraph half way down. }\end{array}$ & $\begin{array}{l}\text { The authors cannot identify where a } \\
\text { capital } A \text { has been used in place of } \\
\text { a lowercase a. }\end{array}$ & $\begin{array}{l}\text { 4. Noted, this is a function of } \\
\text { the collapsing the abstract in } \\
\text { the version I have to review, I } \\
\text { can see it isn't an issue in the } \\
\text { MSWord version }\end{array}$ & \\
\hline
\end{tabular}




\begin{tabular}{|c|c|c|c|}
\hline $\begin{array}{l}\text { Specific contribution to literature } \\
\text { The results do not show a loss if } \\
\text { disciplinary depth of knowledge they } \\
\text { indicate a staff perception of that. } \\
\text { The conclusion in the abstract it not } \\
\text { substantiated by the work. }\end{array}$ & $\begin{array}{l}\text { This sentence has been made more } \\
\text { explicit that the data indicated a } \\
\text { perceived loss of knowledge. }\end{array}$ & 5. Noted & \\
\hline $\begin{array}{l}\text { Educator's should read educators, } \\
\text { the possessive is not required }\end{array}$ & Thank you. Amended. & 6. Noted & \\
\hline
\end{tabular}




\begin{tabular}{|c|c|c|c|}
\hline & & $\begin{array}{l}\text { The document Future } \\
\text { Pharmacists - standards for the } \\
\text { initial undergraduate education } \\
\text { of pharmacists is a set of } 10 \\
\text { standards which are outcomes- } \\
\text { based, the appending } \\
\text { curriculum content is in fact, } \\
\text { input based in that it describes } \\
\text { specific subject areas. This } \\
\text { statement remains incorrect }\end{array}$ & This has been amended. \\
\hline $\begin{array}{l}\text { GPhC is not ...of Great Britain, by } \\
\text { definition it is the UK. This should be } \\
\text { altered }\end{array}$ & $\begin{array}{l}\text { The GPhC is the regulator for } \\
\text { England, Wales and Scotland and } \\
\text { therefore regulates the pharmacy } \\
\text { profession within Great Britain. The } \\
\text { profession in Northern Ireland is } \\
\text { regulated by the Pharmaceutical } \\
\text { Society of Northern Ireland, which is } \\
\text { a separate body. Thus by definition, } \\
\text { the GPhC is not the UK regulator. }\end{array}$ & $\begin{array}{l}\text { 9. My point here is that the } \\
\text { GPhC is just that the '....of } \\
\text { Great Britain' aspect needs to } \\
\text { be removed as it isn't part of } \\
\text { the name of the organisation. } \\
\text { Also, and to correct the } \\
\text { assumption of the authors. the } \\
\text { GPhC actually regulates } \\
\text { pharmacy education in NI on } \\
\text { the basis of an MoA with the } \\
\text { PSNI who visit alongside the } \\
\text { GPhC team and use the } \\
\text { standards and the methodology } \\
\text { when accrediting MPharm } \\
\text { programmes. }\end{array}$ & $\begin{array}{l}\text { This has been amended, } \\
\text { thanks you for clarifying this for } \\
\text { us. }\end{array}$ \\
\hline $\begin{array}{l}\text { The inclusion of the word 'didactic' is } \\
\text { misleading. Integrated and } \\
\text { discipline-based curricula may be } \\
\text { didactic or may be based entirely on } \\
\text { a PBL approach, this has nothing to } \\
\text { do with the degree of integration } \\
\text { within the curricula, these are } \\
\text { separate concepts. }\end{array}$ & $\begin{array}{l}\text { This terminology is mirroring that } \\
\text { within Modernising the Pharmacy } \\
\text { Curriculum. A Refort for the } \\
\text { Modernising Pharmacy Careers } \\
\text { Pharmacist Undergraduate } \\
\text { Education and Pre-Registration } \\
\text { Training Review Team which found } \\
\text { that teaching methods were mostly }\end{array}$ & $\begin{array}{l}\text { 10. Teaching in a didactic way } \\
\text { can be entirely integrated albeit } \\
\text { it may not be engaging, } \\
\text { teaching methods and } \\
\text { integrated curriculum design } \\
\text { are of course linked, but my } \\
\text { point is that one cannot say } \\
\text { didactic teaching lacks }\end{array}$ & $\begin{array}{l}\text { The authors agree. The word } \\
\text { didactically has been removed. }\end{array}$ \\
\hline
\end{tabular}




\begin{tabular}{|c|c|c|c|}
\hline & $\begin{array}{l}\text { didactic (prior to the requirement for } \\
\text { integration in 2010). In views of the } \\
\text { authors, didactic teaching is a } \\
\text { method of teaching, and not of } \\
\text { curriculum design, that has been } \\
\text { shown to be associated with low- } \\
\text { level integration, and so it is } \\
\text { important as a contrast to trans- } \\
\text { integration as outlined by the GPhC } \\
\text { supplement on integration. }\end{array}$ & $\begin{array}{l}\text { integration in the same way } \\
\text { that one cannot guarantee a } \\
\mathrm{PBL} \text { curriculum ensures } \\
\text { integration. }\end{array}$ & \\
\hline
\end{tabular}




\begin{tabular}{|c|c|c|c|}
\hline $\begin{array}{l}\text { Page } 3 \text { last paragraph starts to } \\
\text { discuss Harden's ladder without first } \\
\text { explaining the premise of this } \\
\text { theoretical framework. The work is } \\
\text { not cited here albeit I accept it isa } \\
\text { later in the paper. If this terminology } \\
\text { is to be used here it should be } \\
\text { properly explained and referenced. } \\
\text { The nuance that harden makes is } \\
\text { that no curriculum exists at any one } \\
\text { rung of the ladder but that it will } \\
\text { move up and down the ladder } \\
\text { depending on the learning } \\
\text { experience. This is completely } \\
\text { absent from this paragraph and is } \\
\text { important. }\end{array}$ & $\begin{array}{l}\text { Harden consolidates the work of } \\
\text { others before him to present the } \\
\text { continuum of integration models } \\
\text { contained in discreet "rungs" in a } \\
\text { ladder which builds complexity (as } \\
\text { applied to medical education). } \\
\text { Harden suggests "The 'integration } \\
\text { ladder', by setting out the menu of } \\
\text { choices, encourages teachers to } \\
\text { explore the integration options } \\
\text { available and to discuss the extent } \\
\text { or form of integration most } \\
\text { appropriate in the curriculum" and } \\
\text { "The move from a traditional } \\
\text { subject-based to an integrated } \\
\text { curriculum may involve major } \\
\text { changes. Alternatively, one can start } \\
\text { with something small and } \\
\text { manageable such as a few } \\
\text { integrated themes using a } \\
\text { correlated teaching approach". } \\
\text { The authors believe Harden does } \\
\text { not suggest at any point in this } \\
\text { paper that integration is something } \\
\text { that is stepped up or down. The } \\
\text { GPhC are clear in their } \\
\text { documentation that pharmacy } \\
\text { schools should be aiming for } \\
\text { integration at the top of this ladder. } \\
\text { The nuance here is that the main } \\
\text { flaw with the GPhC's approach to } \\
\text { integration is that they do not allow } \\
\text { an integration continuum, they }\end{array}$ & $\begin{array}{l}\text { 12. The GPhC do accept a } \\
\text { continuum of integration and in } \\
\text { fact it is the case that if } \\
\text { providers attempt to argue, as } \\
\text { some do, that they have a } \\
\text { transdisciplinary level of } \\
\text { integration in their programme } \\
\text { there is little likelihood of this } \\
\text { being accepted. There is } \\
\text { acceptance of early aspects of } \\
\text { the course being located } \\
\text { further down Harden's ladder } \\
\text { but that at some stage students } \\
\text { knowledge should be brought } \\
\text { together at the higher levels of } \\
\text { the ladder. I think Harden's } \\
\text { paper and indeed other authors } \\
\text { in this subject including myself } \\
\text { are clear that there is no } \\
\text { reason why one cannot move } \\
\text { from a lower level of integration } \\
\text { to a higher level later in the } \\
\text { course. Medical education is } \\
\text { almost entirely based upon this } \\
\text { premise with transdisciplinary } \\
\text { education prevailing in later } \\
\text { years }\end{array}$ & $\begin{array}{l}\text { The authors agree that } \\
\text { integration is a continuum, and } \\
\text { the founding literature has } \\
\text { always pertained to this point. } \\
\text { When discussing the } \\
\text { regulator's stance on } \\
\text { integration we are referencing } \\
\text { the GPhC document General } \\
\text { Pharmaceutical Council. } \\
\text { Supplementary Guidance for } \\
\text { Schools of Pharmacy on } \\
\text { Integration. London; } 2015 \\
\text { which outlines expectations of } \\
\text { integration to pharmacy } \\
\text { schools - this is important as it } \\
\text { the only document to the } \\
\text { authors' knowledge that makes } \\
\text { the GPhC's position on } \\
\text { integraton explicit. We } \\
\text { understand that this may mean } \\
\text { by the end of a programme and } \\
\text { not from the beginning. } \\
\text { The manuscript has been } \\
\text { revised to make this clearer. }\end{array}$ \\
\hline
\end{tabular}




\begin{tabular}{|c|c|c|c|}
\hline & $\begin{array}{l}\text { prefer integration at a fixed rung, } \\
\text { which is against the theoretical } \\
\text { framework of integrated curricula. } \\
\text { This section has been reworked to } \\
\text { make this argument more explicit. } \\
\text { The scope of the paper is not to } \\
\text { assume a philosophical discussion } \\
\text { or critique on Harden's work, nor is it } \\
\text { being used as a conceptual tool for } \\
\text { our paper. }\end{array}$ & & \\
\hline $\begin{array}{l}\text { Page } 4 \text { you state you are focusing } \\
\text { on educators views. is it views or is } \\
\text { it experiences? I refer you back to } \\
\text { the point on phenomenology. }\end{array}$ & $\begin{array}{l}\text { This sentence has been edited to } \\
\text { align better with the research aim. }\end{array}$ & 13. Noted & \\
\hline $\begin{array}{l}\text { The interview questions are } \\
\text { confusing to my mind and are not } \\
\text { appropriate for a phenomenological } \\
\text { interview. The relevance of } \\
\text { awareness of the GPhC standards } \\
\text { is a closed question, despite being } \\
\text { described as open here, the answer } \\
\text { is binary. How do these questions } \\
\text { ensure that participants outline their } \\
\text { experiences of integrated curricula? } \\
\text { I accept the open-ended nature of } \\
\text { phenomenology interview scripts but } \\
\text { there does need to be some logic. }\end{array}$ & $\begin{array}{l}\text { There are two main research } \\
\text { questions - now added to the } \\
\text { manuscript. These questions were } \\
\text { operationalised in the research by } \\
\text { asking two broad questions; what is } \\
\text { an integrated curriculum and also } \\
\text { how is integration achieved in your } \\
\text { teaching? Each interview was a } \\
\text { dialogue around these questions. } \\
\text { It would be difficult to provide a full } \\
\text { account of the technicalities of the } \\
\text { interview due to the Journal } \\
\text { restrictions and requirements - short } \\
\text { communication, not research paper. }\end{array}$ & $\begin{array}{l}\text { 14. To the Editor - the } \\
\text { response from the authors in } \\
\text { this case defines the fact this is } \\
\text { not a phenomenology. Neither } \\
\text { of the questions posed relates } \\
\text { to experience of a } \\
\text { phenomenon. This is at the } \\
\text { very base level of this theory. }\end{array}$ & \\
\hline $\begin{array}{l}\text { Was a second researcher involved } \\
\text { in the creation of the coding even } \\
\text { from a point off view of checking the } \\
\text { coding etc? This would be normal } \\
\text { practice in qualitative work albeit the }\end{array}$ & $\begin{array}{l}\text { This comment has been addressed } \\
\text { above in reviewer } 1 \text { comments. } \\
\text { There is now much more narrative } \\
\text { within the manuscript about the data } \\
\text { analysis. }\end{array}$ & 15 Noted & \\
\hline
\end{tabular}




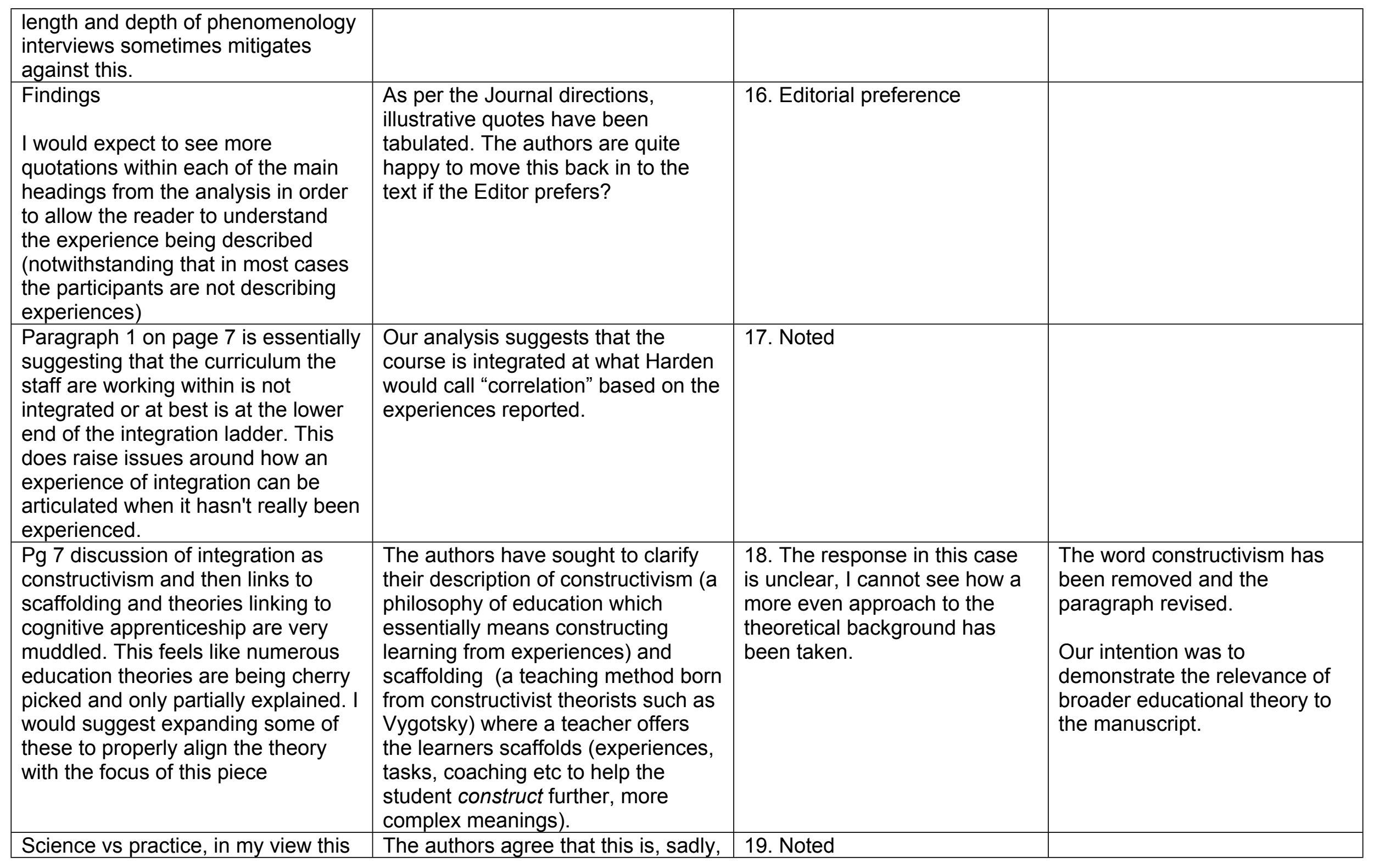




\begin{tabular}{|c|c|c|c|}
\hline $\begin{array}{l}\text { is a very old argument and adds } \\
\text { nothing to this work. The dilution of } \\
\text { curriculum content needs not be a } \\
\text { reflection on practice and thus does } \\
\text { not need to be framed this way }\end{array}$ & $\begin{array}{l}\text { a very old argument, but one which } \\
\text { legitimately surfaces from the data } \\
\text { and as such cannot be ignored. This } \\
\text { was a strong theme, related back to } \\
\text { the GPhC standards for "relevant } \\
\text { science" and (what is seen by } \\
\text { certain participants as) divisive } \\
\text { terminology they employ. Many } \\
\text { participants interpreted the } \\
\text { standards as igniting old flames. } \\
\text { This cannot be ignored in the } \\
\text { analysis and discussion of the data. }\end{array}$ & & \\
\hline $\begin{array}{l}\text { Discussion } \\
\text { References in this section go } \\
\text { beyond the } 39 \text { references within the } \\
\text { submitted paper, has this been } \\
\text { drawn fro elsewhere? The } \\
\text { referencing should be reviewed }\end{array}$ & Reviewed and updated. & 20 Noted & \\
\hline
\end{tabular}




\begin{tabular}{|c|c|c|c|}
\hline & $\begin{array}{l}\text { be argued learning communities } \\
\text { form in any situation, but what we } \\
\text { are saying here is that legitimate } \\
\text { participation is unachievable in the } \\
\text { current curriculum and therefore } \\
\text { CoP (in the pure meaning) are } \\
\text { impossible without sustained } \\
\text { learning in the workplace and so the } \\
\text { highest domains of integration } \\
\text { cannot occur without true workplace } \\
\text { learning. The authors feel that this } \\
\text { supports the interpretation of the } \\
\text { data. }\end{array}$ & & $\begin{array}{l}\text { practice. For us, this lack of } \\
\text { legitimate peripheral } \\
\text { participation in a CoP is why } \\
\text { trans-integration is challenging } \\
\text { in current undergraduate } \\
\text { programmes. }\end{array}$ \\
\hline $\begin{array}{l}\text { The sentence that learners do not } \\
\text { need to utilise skills and } \\
\text { competencies until after graduation } \\
\text { concerns me with respect to the } \\
\text { assessment strategy here, I would } \\
\text { argue that most high-quality UK } \\
\text { MPharm programmes include OSCE } \\
\text { assessments in their assessment } \\
\text { strategies and thus by definition } \\
\text { require this very thing. }\end{array}$ & $\begin{array}{l}\text { The manuscript does not discuss } \\
\text { assessment methods of an } \\
\text { integrated curriculum. Assessment } \\
\text { is beyond the scope of the paper, } \\
\text { and was not an aim for this study. } \\
\text { We agree that exploring how } \\
\text { integration is assessed is an } \\
\text { important and interesting avenue for } \\
\text { research, but feel this would be a } \\
\text { separate area for research. }\end{array}$ & $\begin{array}{l}\text { 22. See point above about } \\
\text { assessment. The statement is } \\
\text { still incorrect students regularly } \\
\text { do this in UK MPharms, some } \\
\text { are actually working in } \\
\text { hospitals as part of their } \\
\text { education, for example learning } \\
\text { dispensing in a live dispensary. } \\
\text { I would be happy if the authors } \\
\text { take away the generalisation } \\
\text { and make the statement } \\
\text { relevant to their own factual } \\
\text { knowledge. }\end{array}$ & $\begin{array}{l}\text { We have made this a site- } \\
\text { specific comment, and have } \\
\text { subsequently edited this } \\
\text { paragraph. }\end{array}$ \\
\hline $\begin{array}{l}\text { Summary } \\
\text { Pharmacy as a modular programme } \\
\text { is described as a historic fact. } \\
\text { Modules were fairly new in the early } \\
90 \text { s and before that curricula were } \\
\text { non-modular. This is not a } \\
\text { particularly long period of time. I }\end{array}$ & $\begin{array}{l}\text { The data did surface strong feelings } \\
\text { about the dilution of "hard science" } \\
\text { and as such this is a legitimate } \\
\text { argument for the manuscript. These } \\
\text { may seem outdated terms s, but the } \\
\text { matter was important for the } \\
\text { participants of this study, particularly } \\
\text { scientists who found curricula }\end{array}$ & 23 Noted & \\
\hline
\end{tabular}




\begin{tabular}{|c|c|c|c|}
\hline $\begin{array}{l}\text { would suggest this is a weak } \\
\text { argument. Equally what do the } \\
\text { authors mean by terms like 'science' } \\
\text { and 'hard science' these are } \\
\text { outdated and to a degree pejorative } \\
\text { terms used by a minority to suggest } \\
\text { that positivist experimental science } \\
\text { trumps all. I would argue this sort of } \\
\text { one dimensional view is not widely } \\
\text { held in the academy and should not } \\
\text { be perpetuated here. }\end{array}$ & $\begin{array}{l}\text { change a challenge to their identity } \\
\text { as teachers. } \\
\text { Educators are also reflecting their } \\
\text { personal journey from teaching as } \\
\text { part of a modular degree and the } \\
\text { tensions this brings to their current } \\
\text { teaching. } \\
\text { This view is not the view of the } \\
\text { authors but that of the participants. }\end{array}$ & & \\
\hline \multicolumn{4}{|l|}{ Reviewer 3} \\
\hline $\begin{array}{l}\text { Abstract: The review template "runs } \\
\text { together" and while this may be } \\
\text { formating issues, the breakdown of } \\
\text { Background, Purpose, Summary, } \\
\text { etc. should be clearly defined. Also, } \\
\text { I would humbly submit that the } \\
\text { abstract is too long and should be } \\
\text { shortened in length. }\end{array}$ & The abstract has been edited. & & \\
\hline $\begin{array}{l}\text { Overall work is detailed, well } \\
\text { referenced, and extremely thorough. } \\
\text { Upon my first reading I seem to get } \\
\text { a little loss in all of the words; } \\
\text { however, when I began to "reread" } \\
\text { the document I was impressed with } \\
\text { how much work the authors had } \\
\text { placed into the manuscript and was } \\
\text { impressed with their efforts. Truly, } \\
\text { the descriptive writing placed me } \\
\text { "within" their institution as you can } \\
\text { almost hear professors saying the } \\
\text { very words that were quoted. Nicely } \\
\text { done--impressive writing style for } \\
\text { this subject. }\end{array}$ & $\begin{array}{l}\text { Thank you for your comments; we } \\
\text { are glad that you have enjoyed } \\
\text { reading the manuscript. We hope } \\
\text { that by addressing certain issues } \\
\text { outlined above the readability of the } \\
\text { manuscript has improved. }\end{array}$ & $\begin{array}{l}\text { - I believe you have } \\
\text { addressed and/or incorporated } \\
\text { most of the three reviewers } \\
\text { comments as requested. I still } \\
\text { maintain that the abstract is too } \\
\text { lengthy and written with way } \\
\text { too many commas; however, I } \\
\text { will leave this to the judgement } \\
\text { of the Editor as this may be } \\
\text { preference for the author (and } \\
\text { the editor). Regardless of the } \\
\text { style, the content is important } \\
\text { to pharmacy education in } \\
\text { general as many schools } \\
\text { (including my own ) attempt to }\end{array}$ & $\begin{array}{l}\text { We have made slight amends } \\
\text { to the abstract in terms of } \\
\text { length and readability. } \\
\text { It is now under } 250 \text { words as } \\
\text { per journal requirements. }\end{array}$ \\
\hline
\end{tabular}




\begin{tabular}{|l|l|l|l|}
\hline & & $\begin{array}{l}\text { get to a very high level of } \\
\text { integration and the authors } \\
\text { addressed this from multiple } \\
\text { angles. }\end{array}$ & \\
\hline $\begin{array}{l}\text { The subject is international in nature } \\
\text { and is very pertinent to current } \\
\text { practice and will be helpful to many } \\
\text { readers. I look forward to seeing } \\
\text { this article in the journal. }\end{array}$ & $\begin{array}{l}\text { Thank you for reviewing the } \\
\text { manuscript. }\end{array}$ & $\begin{array}{l}\text { 1. page 4, line 212--should } \\
\text { Hardens be Harden's } \\
\text { 2. page 4, line 219. The first } \\
\text { sentence in this paragraph is } \\
\text { lengthy and seems to "run on" } \\
\text { with lot's of comma's and the } \\
\text { use of "and". Consider } \\
\text { breaking into multiple } \\
\text { sentences. }\end{array}$ & $\begin{array}{l}\text { 1. Edited. } \\
\text { edited. }\end{array}$ \\
\hline
\end{tabular}




\section{Exploring an integrated curriculum in pharmacy: educators' perspectives}

Andrew Mawdsley, MPharm PGDip (ClinPharm) MEd MPharmS SFHEA FRPSMII

Clinical Lecturer, Division of Pharmacy and Optometry, The University of Manchester, Manchester, UK.

Sarah Willis, BA MA PhD SFHEA

Lecturer in Social Pharmacy, Division of Pharmacy and Optometry, The University of Manchester, Manchester, UK.

\section{Correspondence:}

Andrew Mawdsley

Division of Pharmacy and Optometry

School of Health Science

Faculty of Biology, Medicine and Health

Room 1.135, Stopford Building

The University of Manchester

Oxford Road

M13 9PL

UK

+4401613060593

andrew.mawdsley@manchester.ac.uk

Sarah Willis

Division of Pharmacy and Optometry

School of Health Science

Faculty of Biology, Medicine and Health

Room 1.29, Stopford Building

The University of Manchester

Oxford Road

M13 9PL

UK

+4401612755894

sarah.willis@manchester.ac.uk

There are no conflicts of interest or financial conflicts.

\section{Specific contribution to literature:}

To date how an integrated curriculum is viewed, epistemologically, and subsequently incorporated in teaching practice by educators, has not been investigated. Our analysis suggests that integration is for many an abstract rather than enacted concept; and that although integration is viewed as learnercentered, integration is perceived as being associated with a loss of in-depth learning. Integration is well understood by educators, but is complex to enact in one's own teaching practice. Furthermore, differences in how Faculty members conceptualize the purpose and effects of integration within one institution mean that the level and type of integration reported as having been achieved varied - with the perceived implication that students' development as integrative thinkers may not be happening as intended by curriculum designers. 


\section{Abstract}

Background and purpose Lack of consensus regarding the benefits of an integrated curriculum, and ambiguity concerning what is being integrated within a pharmacy curriculum exists, but how an integrated curriculum is viewed, epistemologically, and subsequently incorporated into teaching practice has not been investigated. This study explores how educators conceptualize, experience and enact curricula integration both pedagogically and organizationally.

Educational activity and setting In-depth qualitative interviews with Faculty members purposively sampled for maximum variation in disciplinary background and teaching experience were undertaken at a single site. Interviews addressed two research questions: how pharmacy educators understand an integrated curriculum and educators' experiences of it.

Findings Analysis of the interview data suggests four essential meanings of integration: integration as a method for organizing teaching and learning; integration as enacted by self and others; integration as tension between conflicting knowledge domains; and integration as an impossible concept to apply to teaching practice. Analysis suggests that integration is an abstract rather than enacted concept and although integration is viewed as learner-centered, integration is complex and associated with a loss of in-depth learning.

Summary Differences in how Faculty members conceptualize the purpose and effects of integration mean that the level and type of integration reported varied. A clearer understanding of the rationale for change, and methods for better applying theory of integration to teaching practice, may be needed to achieve curriculum standards required by bodies accrediting undergraduate pharmacy programmes.

Keywords: Integrated curriculum; curricula change; conceptions of curricula; perspectives on curricula; pharmacy education

There are no conflicts of interest or financial conflicts. 


\title{
Exploring an integrated curriculum in pharmacy: educators' perspectives
}

\begin{abstract}
Background and purpose Lack of consensus regarding the benefits of an integrated curriculum, and ambiguity concerning what is being integrated within a pharmacy curriculum exists, but how an integrated curriculum is viewed, epistemologically, and subsequently incorporated into teaching practice has not been investigated. This study explores how educators conceptualize, experience and enact curricula integration both pedagogically and organizationally.
\end{abstract}

Educational activity and setting In-depth qualitative interviews with Faculty members purposively sampled for maximum variation in disciplinary background and teaching experience were undertaken at a single site. Interviews addressed two research questions: how pharmacy educators understand an integrated curriculum and educators' experiences of it.

Findings Analysis of the interview data suggests four essential meanings of integration: integration as a method for organizing teaching and learning; integration as enacted by self and others; integration as tension between conflicting knowledge domains; and integration as an impossible concept to apply to teaching practice. Analysis suggests that integration is an abstract rather than enacted concept and although integration is viewed as learner-centered, integration is complex and associated with a loss of in-depth learning.

Summary Differences in how Faculty members conceptualize the purpose and effects of integration mean that the level and type of integration reported varied. A clearer understanding of the rationale for change, and methods for better applying theory of integration to teaching practice, may be needed to achieve curriculum standards required by bodies accrediting undergraduate pharmacy programmes.

Keywords: Integrated curriculum; curricula change; conceptions of curricula; perspectives on curricula; pharmacy education

There are no conflicts of interest or financial conflicts.

\section{Background and purpose}

Following the Health Education England (HEE) review of pharmacist education and training in 
2010, ${ }^{1}$ the General Pharmaceutical Council (GPhC) (the professional regulator for pharmacists and pharmacy technicians within the United Kingdom (UK)) introduced "Future Pharmacists". This document is a revised set of ten outcomes-based standards for the initial training and education of pharmacists, with an accompanying indicative syllabus. ${ }^{2} \mathrm{~A}$ core principle in the revised standards for education is curriculum integration, whereby theory is connected to authentic practice, so that knowledge becomes connected, applied, understood and obtainable. ${ }^{4}$ The revised standards require pharmacy schools to replace traditional fragmented curricula "front loaded"4 with isolated modules of science and where there is little or no correlation between science and practice content. 3,4 Transformation of traditional curricula is called for in order to blur the lines between disciplines, address problems with graduates lacking confidence, instill professional ownership and understanding of knowledge, and maximize opportunities for professional socialization. ${ }^{3,5}$ An integrated curriculum is conceptualized as producing graduates who can understand, evaluate, and manage patients with complex drug regimens by drawing on a solid foundation in the basic and clinical sciences as applied to practice. Hence, the intended learning outcomes of integrated curricula are "Future Pharmacists" equipped with the skills, knowledge and behaviors required for pharmacists' new and emerging clinical roles.

While there is a growing body of literature, particularly from medical and social work education, ${ }^{6-}$ ${ }^{20}$ as well as from pharmacy, that integration is an effective method for curriculum design, ${ }^{21-24}$ fewer studies have reported the anticipated learning outcomes of integrated curricula. ${ }^{14,15,25,26}$ For example, it has been reported that integration trivializes difficult concepts, sidelines aspects of understanding, can be unachievable for teachers, learners and institutions, and has little or no impact on learning outcomes, ${ }^{14,15,25}$ with a study comparing graduates of an integrated and modular pharmacy curriculum finding little difference in terms of preparation for practice. ${ }^{26}$

As well as a lack of consensus regarding the benefits of integration, there is also some ambiguity regarding what integration is, with the result that there are multiple ways that integration may be conceptualized within pharmacy curricula. Since it was first proposed by Dewey as a method of connecting distinct but relatable subject disciplines, ${ }^{45}$ the ambiguity regarding integration can be traced back to its multiple definitions, conceptualizations, representations and models of 'integration'. Following its early usage, integration gained prominence in the late 1980's as a solution to issues associated with incoherent formal schooling systems in North America, and was subsequently 
developed conceptually by Fogarty, ${ }^{27}$ Drake, ${ }^{28}$ Jacobs, ${ }^{29}$ and Beane in the 1990 s. $^{12-14}$ Harden $^{30}$ consolidated conceptualizations and representations of 'integration' from these writers within his 'integration ladder', which provides a hierarchy of models and types of integration ranging from isolation of disciplines (the lowest level of integration associated typically with modular curricula) to the highest levels of integration where knowledge is connected and explored in a learners' mind, and where disciplinary boundaries are transcended to allow learners to navigate knowledge in organic ways, with no compartmentalization of knowledge. ${ }^{8}$ It is the highest levels of integration that the $\mathrm{GPhC}^{31}$ requires of pharmacy curricula, stating, "the three models of integration which meet clearly the expectations of Future Pharmacists are "trans-disciplinary" ["a curriculum based around knowledge from real world experiences. Relies on active integration in student's mind over taught course content from teachers"], 'inter-disciplinary' ["a curriculum based around themes, however emphasis shifts towards commonalities between disciplines"] and 'multi-disciplinary' ["a curriculum based around numerous themes which collates together various subject areas"]. It is less clear how 'correlation' and 'complementary' [lower levels of integration] meet the expectations in Future Pharmacists ...[and] do not meet the requirements of the standards'.

With multiple levels at which integration may be conceptualized as a method and structure for programme delivery, how educators make sense of, and then enact these different conceptualizations, is likely to have an impact on the extent to which students develop as integrative thinkers, and on the extent to which the political and theoretical ambitions intended by curriculum change may be achieved. This research explores how educators understand and personally conceive integration, and how these conceptions inform their enactment of different levels of integration.

Focusing on a single pharmacy school with a long tradition of modular pharmacy education, and taking an in-depth, case study approach ${ }^{34}$ to investigating a paradigm shift in curriculum design and delivery within this school, we describe what integration is within a real-life pharmacy education context, and the impact this paradigm shift has on the teaching and learning experience, through how it is perceived by educators. While based on experiences of educators at a single site, findings are likely to resonate with pharmacy curriculum designers internationally, with the Accreditation Council for Pharmacy Education in the United States and the Canadian Council for Accreditation of Pharmacy Programs also promoting integrated curricula ${ }^{35}$ with the result that many pharmacy schools will be introducing integrated approaches to teaching and learning. 
In choosing to focus on Faculty (educator) members' experiences and understanding of integration, this study explicitly focuses on the epistemological challenges of translating integration into teaching practice - a focus that is best explored qualitatively as the study is concerned with investigating the social world in a natural setting using rich description and explanation. Moreover, given this study is concerned with understanding how educators' social reality - or experience of integration - is based on their definition of integration, the research team adopt an interpretivist stance aimed at theory building through an inductive thinking process, rather than a positivist deductive approach that would be more suited to quantifying commonly used methods for addressing curricular integration nationally ${ }^{36}$. We recognize that in focusing on educators' perceptions and experiences we have also not attempted to capture students' experiences of integration or of how a curriculum supports their development as integrative thinking. While beyond the scope of this study, further work will focus on how students experience integration and their conceptions of it.

\section{Educational activity and setting}

How educators interpret, understand and identify with pharmacy education is not well understood, but ultimately defines what is taught, and how this is taught. In the context of a pedagogical and organizational paradigm shift that challenges prior teaching practice, we collected data from educators within a single educational institution, who have experienced integration to gain insight into the curriculum paradigm as experienced by them at that institution. The study focussed on what integration means to the participants, how this is related to their experiences of teaching, and the influence this had on their teaching practices. The nature of the inquiry allowed the researchers to further explore relationships educators had with each other, and with the institution in which they work, as influences on these meanings and interpretations. As such, the following research questions were developed:

1. How do pharmacy educators understand an integrated curriculum? (meaning)

2. How have educators approached implementing curriculum integration? (experience)

Sampling was purposive to capture a range of perspectives from teachers with different backgrounds and roles within the curriculum; the research team recruited scientists and pharmacy practitioners from Lecturer through to Professor grade employed in teaching-only and teaching and 
research roles. The team aimed to recruit a maximum of ten participants to undertake individual indepth semi-structured interviews, as data saturation is estimated as requiring a maximum of eight to ten participants. ${ }^{37}$ The respondents were from diverse disciplinary backgrounds including pharmacists, pharmacologists, physiologists, immunologists, and pharmacy practice educators with a background in sociology and epidemiology (see Table 1). Respondents were sampled for maximum variation based on their involvement in curriculum design, leadership role within the undergraduate programme, and research and teaching commitment to capture different perspectives on the research questions. The team considered that capturing the perceptions and experiences of participants ranging from junior teaching staff heavily involved in delivery but less so in curriculum design to senior leaders responsible more for design than delivery would contribute to an understanding of the phenomenon and gather an authentic insight into educators' conceptions of integration. Although the research team acknowledge that grade is not a direct indicator of teaching load, or curriculum design responsibility, it was used in our sampling to ensure that the study captured the experiences of integration at both a micro delivery level and of more senior staff overseeing the curriculum at the macro level. Furthermore, in addition to sampling participants according to academic grade perspectives of those who have significant research and/or management responsibilities within the curriculum and of those overseeing the operationalization of integration vertically and horizontally through the programme were also sought.

Prior to starting data collection, research ethics approval was sought and granted. All participants were asked to read a participant information sheet and sign a written consent form in advance of taking part in a face-to-face, one-to-one interview. Interview questions were piloted before data collection for the main study began, to review the questions and the questioning technique. Following this pilot work, the number of interview questions was reduced to two initial prompting questions; in your perspective/role as $\mathrm{XXX}$ what are you trying to achieve by your teaching? And are you aware of the integrated curriculum requirements the GPhC have outlined? All further questioning was responsive to the individual dialogue that occurred during the interview rather than directive, as interviews were approached from a position of flexibility, allowing for participants' accounts of their experiences of integration to generate rich and in-depth data.

The first author recruited participants and conducted the interviews. All interviews were audiorecorded, transcribed, and anonymized to preserve the integrity of respondents. The interviews 
ranged from 40 to 70 minutes, and were conducted in a private office to preserve anonymity. Transcriptions were coded independently by the authors using the constant comparative approach ${ }^{38}$ to systematically identify and map codes, themes and meta-themes within the data. Multiple coding allowed for the refinement of coding, with the authors discussing the themes and their interpretation to identify alternative interpretations and competing explanations before achieving consensus. As well as adopting this systematic process, the authors were mindful of the need to 'bracket' their own preconceptions and experiences of integration in order to interpret the transcripts naively - for example, we identified our own multiple conceptualizations of integration as a possible bias and distortion and sought to avoid imposing our interpretations of integration onto participants' narratives about their experiences of integration. Through this, descriptions given by participants were broken down into distinct meaning-laden statements (codes and themes) that were then further analyzed to identify those that were essential to the phenomenon under study to identify what mattered to the participants about the topic (integration) and to identify the meaning of integration for the participants. We then constructed our interpretation of 'integration' constituted by these discovered essential meanings, experiences, and their interrelationships to theorize from evidence within the data.

\section{Findings}

In total, eight participants from a range of disciplines and grades consented to take part in an interview. To protect participants' anonymity, all illustrative quotes presented in the findings appear as pseudonymous identifiers (see Table 1).

Analysis of the data suggested four essential meanings, or conceptions, of integration;

1. Integration as a method and structure for curriculum design (abstraction)

2. Integration as enacted by self and others (teaching practice)

3. Integration as tension (science versus practice)

4. Integration as impossible (barriers to implementing curriculum change)

Illustrative quotes to support each are incorporated with our descriptions below, with further data presented in Table 2.

Integration as a method and structure for curriculum design 
All participants were aware of the policy drivers underlying moves to reform and integrate curricula, however, none could precisely define an integrated curriculum. Rather, they talked about "vertical", "horizontal" and "spiraling", suggesting an abstract understanding of integration as a method and structure for curriculum design where content is ordered and revisited, that involves linking practice and science, and where integration allows for the application of knowledge to clinical practice. Descriptions frequently incorporated the GPhC conceptualization of integration as involving 'relevant science in practice', ${ }^{2}$ and a sequencing of material in an ordered, connected and relevant fashion.

"it's not just about integrating different topics, but integrated from year one to four, so some sort of spiraling as well as being integrated between the years as well as between the different subject areas ... and it's supposed to bring in more exposure to practice, getting some practice based learning" R5

Educators experienced some anxiety concerning integration; they recognized that they did not fully understand it, were confused by it, and described their experiences of integration in terms of loss of mastery of knowledge and autonomy. Participants attributed this loss to the reduction of didactic teaching, suggesting a misunderstanding between teaching methods and curriculum design. Moreover, participants reported struggling with integration as a method and structure for delivering content because - despite macro changes to the curriculum design - the overall delivery remained essentially modular, with individual subjects taught separately, albeit better connected and sequenced. Thus, for many of those taking part in this study, integration was experienced as involving renaming content as opposed to integrating that content, with educators teaching and planning their teaching in disciplinary silos, without a clear vision of what is taught outside their own discipline, and where depth of understanding of a subject had been sacrificed for breadth of knowledge.

Yet despite this experience of loss of mastery of their own subject, participants recognized that the purpose of integration as a method and structure for curriculum design and delivery of content was to produce better pharmacists rather than to produce graduates who were experts in their own discipline, "to deliver the science in the context of pharmacy". To achieve this, educators acknowledged that teaching needed to be focused on making learning happen; and because teachers characterized learners as naïve to integrated teaching and as needing to be explicitly shown integration for integrative learning to take place, teachers described adopting a developmental 
paradigm in their teaching.

"It is abandoning selfishness, if you like. I mean we are not trying to achieve our own personal targets but our efforts concentrate on meeting their needs rather than meeting our aspirations" R1

Integration, then, was conceptualized as offering learners scaffolds to connect new meaning between knowledge and showing learners how to construct new understandings through vertical and horizontal integration of knowledge, connecting theory to its practical application.

"They [students] don't have the breadth of knowledge, yeah? They don't have this wide knowledge that can connect things together. You need to facilitate that initially" R5

\section{Integration as enacted by self and others}

Examples of how integration was enacted suggest that participants viewed themselves as more likely to integrate than their colleagues. Although teachers were likely to describe themselves as having changed their approach - that is, they considered themselves as having enacted integration they were less likely to consider others as having changed their teaching practice. Participants described shifting a modular curriculum, born from the paradigm of delivering knowledge, to an integrated curriculum where explicit connection of disciplines through methods known to promote knowledge integration, as being difficult for others.

"People have been forced to do integration so sometimes the integration isn't the best example of how it should be done because it's an add-on to what they are doing rather than thinking, how can we integrate and designing their teaching around that" R4

One explanation for why some experienced difficulty in enacting integration related to whether a Faculty member had a teacher identity. Here, Faculty with a dual teaching and research role, who experience conflicting priorities between these roles, and who therefore do not experience teaching as their only identity, were viewed by those who define their purpose as educators as challenging the extent to which integration was possible. Staff prioritizing research over teaching, on the other hand, viewed teachers as lacking academic prowess. 
"The people who do well, do so to the detriment of their teaching. And the people on teaching focused contracts are not well respected by a lot of people on teaching and research contracts, because they're seen to be less" R6

Questions of identity and teachers' legitimacy as educators were raised in relation to participants' experiences of enacting integration. This questioning subsequently brought about a hegemonic challenge to how some Faculty should educate.

"I think it's quite threatening to that whole identity, isn't it? Because if you see what you do as being important and then somebody says actually, it's not important any more... a lot of the science teachers here are not pharmacists and actually a lot of them seem to have less understanding of pharmacy practice than I do" R5.

\section{Integration as tension (science versus practice)}

Experiences of integration were characterized by the tension between science teaching and pharmacy practice; a tension grounded in ideological conflicts over the content of formal and informal learning in pharmacy education. ${ }^{39}$ Practitioners and scientists alike viewed science as core to pharmacy education, but were unsure of its place and emphasis as the profession and its training evolves. The GPhC make a specific recommendation within the curriculum standards that practice should be underpinned by relevant science. Here, respondents felt that the pure science, or 'hard' science, was being diluted by integration, reflecting personal fears and beliefs about curriculum reform.

"I hear from my colleagues ... they [students] don't have enough of the underpinning knowledge that they have been somehow deprived of that learning, and therefore when they go out into practice they might be great communicators ... they might be better prepared for practice ... but if you were asking them to understand the chemical structures underlying a drug interaction, they might not get that because they haven't got that same scientific knowledge" R5

It was acknowledged that science teachers may find it harder to enact curriculum change, and that although they may be willing to move towards tighter affinity between teachers of all disciplines, they were not truly integrated. 
“The scientists come from a pure science background and they've never been exposed to a programme like this before ... that pharmacy is more than just the chemical structure of a drug, if you don't have that background you don't see the importance of it" R6

There was some speculation about the impact this might have on learners and the experienced curriculum. Here, participants commented that learners would undoubtedly recognise the tension between science and practice despite attempts to integrate the two equally.

"I think the learners get really conflicting messages ... I am sure the message that they get is actually the underpinning science is the most important bit. And the other bits are quite artificial; just like the icing on the cake... There is more respect from students for the hard scientists than there is for the practice team. They probably think that sort of knowledge is less important; it will help them get a job but it won't necessarily help them to pass exams" R5.

\section{Integration as impossible}

Since integration was experienced as difficult to enact, many participants questioned whether it was worth the effort. Strong feelings of doubt towards the impact, and measurable outcomes of integration, were voiced.

"Where's the evidence? People in Universities aren't daft ... we'll have to wait another generation to see if they are any better. We should have held them to task and say why are you doing this? What is your hard evidence?" R7

Implementing an integrated curriculum was associated with issues of time, workload, loss of content, a challenge to identity and the organizational culture of the teaching environment, staff cohesion, and sharing of teaching practices. Age, confidence in teaching, and the differing backgrounds of the teachers, and their purpose and role in education were also barriers. The challenges of transformational curriculum change were perceived as impossible to navigate within the established structure of the School and also as requiring transformational change of educators, and how they educate, that participants were unable to meet.

"I don't think we achieved the integration we could have done if we'd started from scratch and really thought about what we needed in the course ... everybody's trying but I think if we had the time rather 
than rejig everything, took a fresh pair of eyes and looked at it properly and not said "I have this lecture where can I fit it?" R4

\section{Discussion}

This study, which adopted an in-depth approach to investigate how an integrated curriculum is viewed, epistemologically, and subsequently incorporated in teaching practice by educators, has found that integration is a complex and uneven process. Participants' accounts of integration varied, with descriptions of integration including reference to curriculum design such as rearrangements of content or changes to teaching and learning, as well as involving tensions between subject areas and difficulties in applying the theory of integration to teaching practice.

Ontologically, as a qualitative study, findings are not intended to be generalized beyond the single case study site. Rather, the results reflect the lived experiences of curriculum reform of the eight participants - and their specific experiences of enacting integration in the context of undergraduate pharmacy education in the UK. However, this study provides some potentially important insights into the barriers that may be experienced outside the study site by those attempting to implement curriculum reform. Internationally, as curriculum designers revise and reform their own curricula, based on the results presented here, it is likely that findings have some transferability to other settings. Of note is the ways in which the intentions of reform may be interpreted and enacted differently by Faculty to how they are intended by curriculum designers. This study highlights that curriculum reform is enacted in ways unintended by curriculum designers, an important message for all educators involved in curricula change.

The reform introduced at the case study site was large scale, pedagogic and paradigmatic, with the result that discourses of teaching identity and the purpose of pharmacy education were actively being questioned and contended at the time that data collection took place. Participants revealed, by their examples, not only the meanings they themselves ascribed to integration - that is, what integration is, but also why integration is important and how integration is enacted, both personally and by other Faculty, as well as and barriers to its enactment. A discussion of these follows.

\section{What is integration and why is it important?}

Integration in curriculum design can take place at a number of different levels - from relative 
isolation of disciplines where integration consists of little more than signposting to other knowledges within the curriculum, to a transcendence of knowledge boundaries where knowledge is connected and explored in a learners' mind (integrative), within the world, beyond subject boundaries, immersing the learner in holistic knowledge..$^{8,13,14}$ This transcendence of disciplines is intended to allow learners to navigate knowledge in organic ways; there is no compartmentalization of the knowledge, it is intertwined, socially applied and broadly mastered. ${ }^{14}$

Respondents' meanings of integration varied - they included integration of knowledge types (science and practice) and integration of knowledge as applied in the workplace. Conceptualizations were shaped by the milieu and context of the working environment, identity as a teacher, and intentions for teaching. Amongst those taking part in the study, teaching for Integration was conceptualized as being learner-centered, and involved making explicit links between subjects to guide the learner in making connections between knowledge, and hence descriptions drew on an understanding of integration as facilitating integrative learning. However, participants recognized that integration had forced a rationalization of teaching and that issues previously noted (concerning the loss of in-depth subject teaching, ${ }^{40}$ loss of subject integrity ${ }^{8}$ and shortcomings in teachers' ability to design curricula and integrated assessment) ${ }^{41}$ challenged their conceptions of integration as an important method and structure for delivering content.

\section{How is integration enacted?}

Descriptions of how integration was enacted suggest that at the case study site it was not situated within the higher domains of multi-, inter- or transdisciplinary integration ${ }^{30}$ but was in fact correlated. Correlation, as defined by Harden, is when "the emphasis remains on the disciplines or subjects with subject-based courses taking up most of the curriculum time. Within this framework, an integrated teaching session is introduced in addition to the subject-based teaching. This session brings together areas of interest common to each of the subjects" ${ }^{30}$ Although this is legitimate, it suggests that more work is needed to achieve a higher level of integration where learners do not compartmentalize knowledge, but approach knowledge in a dynamic and fluid way and become integrative thinkers. Based on findings from this study it would appear that it is easier to integrate in name, than it is to enact - and as such, the intended learning outcomes of integration may not be achieved by learners. 
Another way in which integration was enacted at a more inter-disciplinary than trans-disciplinary level was evident in the lack of workplace-based teaching and learning, and the focus on application of theory to practice situated within the formal structures of University, rather than the authentic clinical setting. The implication of this is that the level of integration at the case study site may be limiting the extent to which learners are able to form genuine connections to practice since they do not become aligned to the community of practice ${ }^{42}$ until graduation and that the navigation from novice through to expert will only happen when the learner is in the workplace. Since becoming a member of a community of practice is through professional socialization, for learners alienated from the community, trans-disciplinary integration is likely to remain elusive for undergraduate learners.

\section{What is stopping integration from happening?}

At the case study site, subject knowledge had been the prior structure for organizing teaching. Post-reform, some participants reported reaching the limitations of their personal competence and finding it difficult to think differently about knowledge to rationalize their teaching to that which is relevant and applied to practice. A barrier to enacting curricula reform, then, is an understanding of the synergy between science and practice. Curriculum reform at this institution had provided a vehicle for increasing awareness and contrast between disciplines, but had not facilitated the transcendence of knowledge beyond individual subjects. Thus, instead of allowing for new approaches to teaching and learning, an unintended consequence of the new curriculum was the distancing of disciplines rather than the drawing of subject matters closer, and hence a widening of the gap between science and practice.

One reason for this was that questioning the relevance of content for undergraduate pharmacy education also threatened the relevance of a teacher's subject, and hence their purpose as a teacher. This challenge to beliefs and identity is demanding, and may explain why integration in pharmacy education seemed difficult and onerous for participants in this study. These tensions are embedded in the nature of pharmacy as a magpie of disciplines, and the question of what defines relevant science is left unanswered and requires further exploration and explanation. Over-coming uncertainty regarding content and how it integrates requires clarity of vision and communication of that vision; yet at the time of data collection for this study there was some reported skepticism regarding curriculum integration that will need addressing in future through participation and involvement of teachers, 
supported by definitions of integration that can be meaningfully enacted by Faculty together with indicators of success.

Curricula are defined by the people, culture, history, intentions and context of the school and its educators. ${ }^{29}$ These institutional and contextual obstacles make the redesign and evaluation of curricula difficult.4:20 To enact the intended curriculum, the environment must foster cooperation, mutual engagement, unified understanding and teacher involvement. ${ }^{9}$ This is important in pharmacy, where there is a long-established division between pharmaceutical science and pharmacy practice. $^{22}$ Contention over the balance of science and practice teaching is long-running, reflected in the historic modular approach to pharmacist education and training, as opposed to a harmonious integration between pure and applied sciences. This separation of knowledge, removed from applied context, is evident in beliefs that learners struggle to connect conceptual disciplines to clinical context. ${ }^{7,24}$

Integration forced those taking part in our study to reconsider the assumptions that undergraduate pharmacy education had traditionally been based upon, and to review which knowledge is important to teach, and for what purpose it is taught. Consequently, many interpreted the need for 'relevant science' as synonymous with a loss of science, instead of the intended outcome of reform which is to be learner-centered, with applied science teaching. Integration challenged individuals' teaching (methods, delivery, content and knowledge), and their personal teaching identity, creating anxiety amongst participants over their purpose for teaching, and therefore place within the curriculum. Teachers that identify themselves as a member of certain knowledge community are viewed as those more likely to resist change, ${ }^{43}$ which may offer clues to why academic pharmacy practitioners are more comfortable in adopting a transdisciplinary model in contrast to non-pharmacist counterparts, because they belong to the unique knowledge community of pharmacy practice, having been trained in all the individual disciplines themselves. Anxieties expressed by certain participants exposes the conflict to teaching identity that integration can cause, and therefore raises concerns over how achievable higher-level integration is, reflecting the tensions caused by changing educational conceptions within the context of pharmacy.

We acknowledge the limitations of this study; small sample size of educators based in one institution drawing on the perceptions of the participants as a snapshot in time.

\section{Summary}


Undergraduate pharmacy education has undergone substantive change in the UK and internationally which has forced pharmacy educators to reevaluate their conceptions for teaching and learning and revisit how, and for what purpose, they teach. Based on interview participants' meanings of curriculum integration, and how it may be enacted, a complex picture emerges of the difficulties in moving from discipline-based to integrated curricula, and of the ongoing tension between science and pharmacy practice ${ }^{35}$. Our research provides further evidence of issues commonly seen with integrated curricula, of problems with clarity of definition, time, staff resistance, enacting theory, measuring impact and outcomes, content loss and teaching methods. $9,14,15,20,25,40,43$

Analysis of the data shows that pharmacy remains an applied science as opposed to a programme designed and delivered for clinical training. This is in part due to pharmacy's historic roots as a science-heavy, modular programme, and reinforced by the lack of substantive practice placements and internships offered within the degree ${ }^{3}$. This leaves the curriculum in a state of limbo where intentions for teaching and learning are not being fully realized; current limited authentic application of knowledge to practice makes university-based teaching abstract and not integrative. Educators have struggled to teach distinct knowledge in a way that defines pharmacy as a unified subject ${ }^{6}$. This is in part due to the destination careers of pharmacists being diverse, and a Faculty which is equally varied.

Further research will explore student perspectives of integration, and investigate how learners conceptualize and characterize integration in terms of learning and assessment.

\section{References}

1. Smith A, Darracott R. Modernising Pharmacy Careers Programme. Review of Pharmacist Undergraduate Education and Pre-Registration Training and Proposals for Reform. London; 2011.

2. General Pharmaceutical Council. Future Pharmacists. Standards for the Initial Education and Training of Pharmacists. London; 2011.

3. Guile D, Ahamed F. Modernising the Pharmacy Curriculum. A Report for the Modernising Pharmacy Careers Pharmacist Undergraduate Education and Pre-Registration Training Review Team. London; 2011.

4. Winch C, Clarke L. "Front-loaded" Vocational Education versus Lifelong Learning. A Critique of Current UK Government Policy. Oxford Rev Educ. 2003;29(2):239-252. 
5. Waterfield J. Is pharmacy a knowledge-based profession? Am J Pharm Educ. 2010;74(3): Article 55.

6. Alsharif NZ. Curriculum Integration: A Self-Driven Continuum. Am J Pharm Educ. 2014;78(1): Article 2.

7. Barlow JW, Strawbridge JD. Teaching and assessment of an innovative and integrated pharmacy undergraduate module. Pharm Educ. 2007;7(2):193-195.

8. Beane JA. Curriculum Integration and the Disciplines of Knowledge. Phi Delta Kappan. 1995;76(8):616-622.

9. Beane JA. Problems and Possibilities for an Integrative Curriculum. Middle Sch J. 1993;25(1):1823.

10. Benor DE. Interdisciplinary integration in medical education: theory and method. Med Educ. $1982 ; 16(6): 355-361$.

11. Brauer DG, Ferguson KJ. The integrated curriculum in medical education: AMEE Guide No. 96. Med Teach. 2015;37(4):312-322.

12. Karimi R, Meyer D, Fujisaki B, Stein S. Implementation of an Integrated Longitudinal Curricular Activity for Graduating Pharmacy Students. Am J Pharm Educ. 2014;78(6): Article 124.

13. Kysilka M. Understanding integrated curriculum. Curric J. 1998;9(2):197-209.

14. Mason TC. Integrated curricula: Potential and problems. J Teach Educ. 1996;47(4):263-270.

15. Muller JH, Jain S, Loeser H, Irby DM. Lessons learned about integrating a medical school curriculum: Perceptions of students, faculty and curriculum leaders. Med Educ. 2008;42(8):778-785.

16. O'Neill PA, Morris J, Baxter C-M. Evaluation of an integrated curriculum using problem-based learning in a clinical environment: The Manchester experience. Med Educ. 2000;34(3):222-230.

17. Rosse C. Integrated versus discipline-oriented instruction in medical education. $J$ Med Educ. 1974;49(10):995-998.

18. Schmidt HG, Machiels-Bongaerts M, Hermans H, Ten Cate TJ, Venekamp R, Boshuizen HPA. The development of diagnostic competence: Comparison of a problem-based, an integrated, and a conventional medical curriculum. Acad Med. 1996;71(6):658-664.

19. Sylvia LM, Reynolds JR, Huff NA, Schollard RJ. Experience with a non-traditional doctor of pharmacy program based on an integrated, andragogical model. Am J Pharm Educ. 2003;67(1): Article 23. 
20. Tresolini CP, Shugars DA, Lee LS. Teaching an integrated approach to health care: Lessons from five schools. Acad Med. 1995;70(8):665-670.

21. Katajavuori N, Hakkarainen K, Kuosa T, Airaksinen M, Hirvonen J, Holm Y. Curriculum reform in Finnish pharmacy education. Am J Pharm Educ. 2009;73(8): Article 151.

22. Husband AK, Todd A, Fulton J. Integrating Science and Practice in Pharmacy Curricula. Am J Pharm Educ. 2014;78(3): Article 63.

23. Pearson ML, Hubball HT. Curricular Integration in Pharmacy Education. Am J Pharm Educ. 2012;76(10): Article 204.

24. Wensel TM, Broeseker AE, Kendrach MG. Design, implementation, and assessment of an Integrated Pharmacy Applications course series. Curr Pharm Teach Learn. 2014;6(5):706-715.

25. Brophy J, Alleman J. A caveat: curriculum integration isnt't always a good idea. Educ Leadersh. 1991;49(2):66.

26. Whelan AM, Mansour S, Farmer P, Yung D. Moving from a lecture-based to a problem-based learning curriculum-perceptions of preparedness for practice. Pharm Educ. 2007;7(3):239-247.

27. Fogarty R. How to Integrate the Curricula. Illinois: IRI/Skylight Training and Publishing Inc; 1991.

28. Drake SM. Planning Integrated Curriculum. Virginia: Association for Supervision and Curriculum Development; 1993.

29. Jacobs HH. Interdisciplinary Curriculum: Design and Implementation. Virginia: Association for Supervision and Curriculum Development; 1989.

30. Harden RM. The integration ladder: a tool for curriculum planning and evaluation. Med Educ. 2000;34(7):551-557.

31. General Pharmaceutical Council. Supplementary Guidance for Schools of Pharmacy on Integration. London; 2015.

32. Harden RM. What is a spiral curriculum? Med Teach. 1999;21(2):141-143.

33. Spelt EJH, Biemans HJA, Tobi H, Luning PA, Mulder $M$. Teaching and Learning in Interdisciplinary Higher Education: A Systematic Review. Educ Psychol Rev. 2009;21(4):365-378.

34. Yin RK. Case study research: Design and Methods. (3rd Ed, Vol 5) Thousand Oaks CA: Sage; 2003.

35. Waterfield J. Using Bourdieu's Theoretical Framework to Examine How the Pharmacy Educator Views Pharmacy Knowledge. Am J Pharm Educ. 2015;79(10): Article 153. 
36. Neuman WL. Social research methods: Qualitative and Quantitative approaches. Boston: Allyn and Bacon; 1997.

37. Reid K, Flowers P, Larkin M. Exploring lived experience: An introduction to interpretative phenomenological analysis. Psychologist. 2005;18(1):20-23.

38. Bliss J, Monk M, Ogborn J. Qualitative Data Analysis for Educational Research. London: Croom Helm; 1983.

39. Jesson JK, Langley CA, Wilson KA, Hatfield K. Science or practice? UK undergraduate experiences and attitudes to the MPharm degree. Pharm World Sci. 2006;28(5):278-283.

40. Dahle LO, Brynhildsen J, Fallsberg MB, Rundquist I, Hammar M. Pros and cons of vertical integration between clinical medicine and basic science within a problem-based undergraduate medical curriculum: examples and experiences from Linköping, Sweden. Med Teach. 2002;24(3):280285.

41. Hudson J., Tonkin A. Evaluating the impact of moving from discipline-based to integrated assessment. Med Educ. 2004;38(8):832-843.

42. Lave J, Wenger E. Situation Learning: Legitimate Peripheral Participation. Cambridge: Cambridge University Press; 1991.

43. Lam TP, Irwin M, Chow LWC, Chan P. Early introduction of clinical skills teaching in a medical curriculum - factors affecting students' learning. Med Educ. 2002;36(3):233-240. 
Table 1: Participant characteristics.

\begin{tabular}{|c|c|c|c|c|c|c|c|c|c|c|c|}
\hline \multirow[t]{2}{*}{ Identifier } & \multicolumn{2}{|c|}{ Discipline } & \multicolumn{3}{|c|}{ Grade } & \multicolumn{4}{|c|}{ Role in curriculum } & \multicolumn{2}{|c|}{ Gender } \\
\hline & Scientist & Pharmacist & Lecturer & $\begin{array}{l}\text { Senior } \\
\text { Lecturer }\end{array}$ & Professor & $\begin{array}{l}\text { Teaching: } \\
\text { science }\end{array}$ & $\begin{array}{l}\text { Teaching: } \\
\text { practice }\end{array}$ & $\begin{array}{l}\text { Leadership } \\
\text { role }\end{array}$ & $\begin{array}{c}\text { Non- } \\
\text { leadership } \\
\text { role }\end{array}$ & Male & Female \\
\hline R1 & $\checkmark$ & & & $\begin{array}{c}\checkmark \\
\text { (Teaching } \\
\text { and } \\
\text { research) }\end{array}$ & & $\checkmark$ & & $\checkmark$ & & $\checkmark$ & \\
\hline R2 & $\checkmark$ & & & $\begin{array}{c} \\
\text { (Teaching } \\
\text { and } \\
\text { research) }\end{array}$ & & $\checkmark$ & & $\checkmark$ & & $\checkmark$ & \\
\hline R3 & & $\checkmark$ & $\begin{array}{c}\checkmark \\
\text { (Teaching } \\
\text { only) }\end{array}$ & & & & $\checkmark$ & & $\checkmark$ & & $\checkmark$ \\
\hline R4 & $\checkmark$ & & $\begin{array}{c}\checkmark \\
\text { (Teaching } \\
\text { and }\end{array}$ & & & $\checkmark$ & & $\checkmark$ & & & $\checkmark$ \\
\hline
\end{tabular}




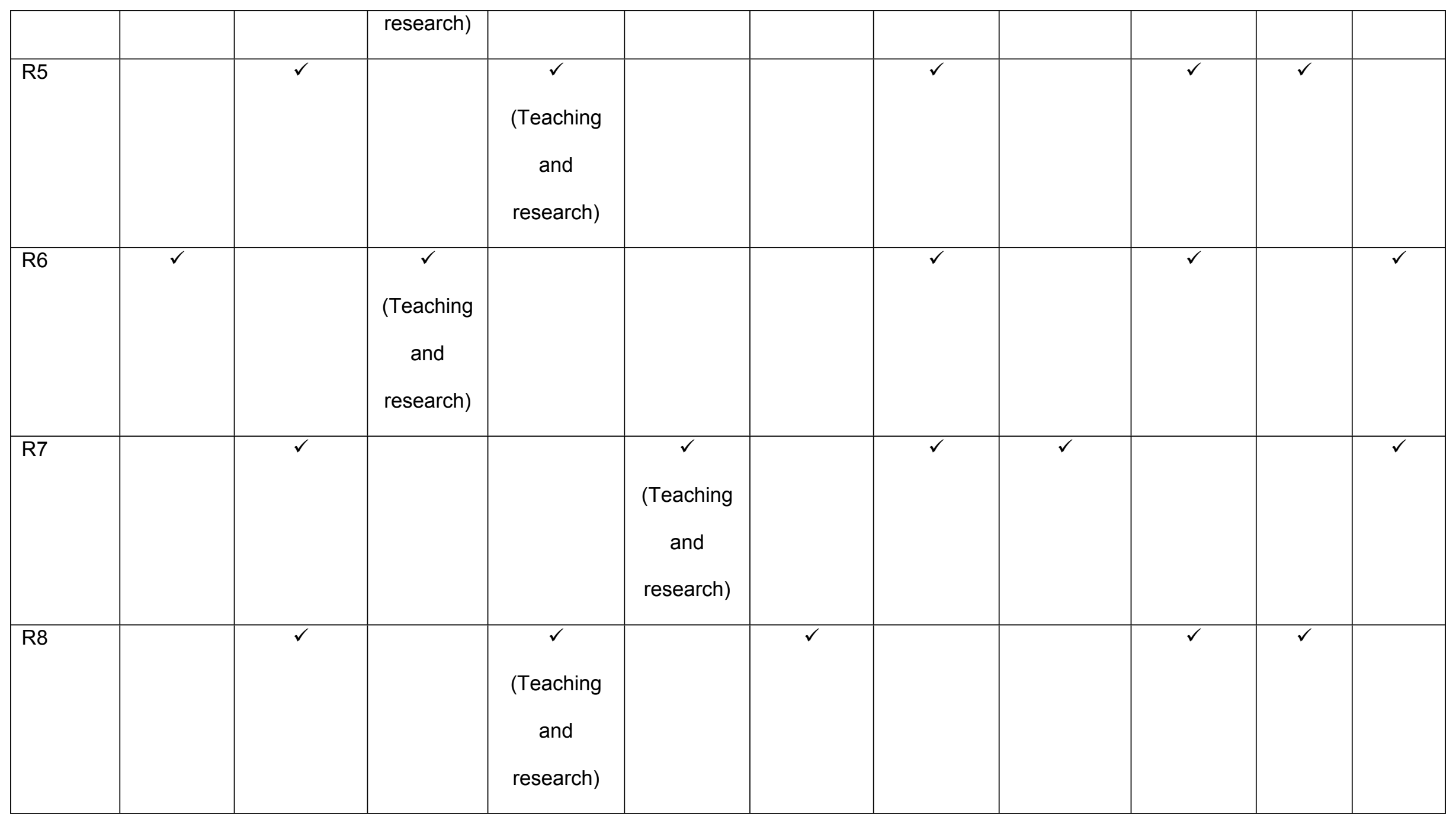




\section{Table 2: Illustrative Quotes}

Integration as a method and structure for curriculum design (abstraction)

"There is that ladder thing isn't there, where they are meant to do it in their heads? I don't understand the difference between the extremes of the scale ... to practice as a pharmacist they have to integrate it in their head otherwise they can't do their job. So what's the difference between the top and the bottom?" R4

"We were told to integrate but there is no definition of integration. There is no gold standard so how do we know if we ever met it or not?" R8

"We have got to put clearly signposted stepping stones out for them so they know how to get from a piece of chemistry, into a drug, into a patient" R7

"They are struggling with the amount they need to know; the breadth of knowledge. They're learning to apply information, which is good, but what about the content? I don't know whether they know anything. Maybe losing a bit of the knowledge, the "knows how" or "knows" for the "shows how". When we are doing OTC you're trying to get them to relate things back, muscarinic receptors and antihistamines, so what receptors do they work at? What are the side effects? I couldn't get it out of them. I was like, come on, you did this in second year" R4

\section{Integration as enacted by self and others (teaching practice)}

“There isn't an established career for people to be really good teachers, most of the esteem goes with your research so why would you spend a lot of time trying to innovate with your teaching? ... Research is king and it's the most important thing we do. And oh yeah, by the way, we happen to have a couple of hundred young people around to get in the way a little bit" R5

"Old academic careers involve a few hours of teaching and a lot of research ... there is a legacy of staff who've had different experiences and now they are very senior, they bring in a lot of research income ... you couldn't discipline somebody because they don't buy in to a new philosophy of teaching! So what are you going to do with 


\section{them? I sense people are waiting for them to retire" $R 5$}

"What we actually need to do in the end is teach students to be pharmacists ... the [regulator] are saying you have to produce good clinical pharmacists for our communities, but the university is saying we need to have good pharmaceutical research. That's the real problem" R6

"A lot of practice people were bought into schools about 15 years ago when we were starting to think, ooh, we need to do some practical work, but they didn't have any particular educational credentials. I'm not saying they are silly or anything, it just creates a spectrum; somebody who's designing molecules and looking at the highest levels of molecular modeling at one end, and well, how do you bring these people together?" R7

"Staff in the science section think it's [integration] jumping through hoops for the sake of jumping through hoops, although some have really embraced it. Maybe because they are not pharmacists they have maybe not had to integrate other disciplines to make sense of one job, unless you've done a similar degree l'm not sure you'd understand why it's important" R4

\section{Integration as tension (science versus practice)}

"There's always been a split in terms of science and practice ... pharmacy has become more clinical but I think it's really important that pharmacists understand the basic concepts of chemistry, physics and biology, not having that is bad" R6

"I do hear quite a lot of science colleagues worried that we're trying to shift away from science, or hard science. I can't see that there are fundamental chunks missing, the scientists always think their stuff is more important, they always have" R8 "I don't think we are cheapening the science in a pharmacy degree, unlike some of my colleagues very against integration. They think it's downgrading the science. We haven't lost things through integration, but we've got to be careful, got to be mindful, keep good science, the best science, and then show the students what it means" R7 
"The science people are actually probably doing more because they realize ... they have to identify where they fit into practice. But what I am seeing is that the people in practice aren't including the chemistry ... they aren't going back and linking practice back. But the scientists are reading, and going to meetings and listening to the messages that we need to move to a clinical programme. I think they worry they are going to be lost. So it's a matter of job security" R6

\section{Integration as impossible (barriers to implementing curriculum change)}

"I think that the idea for integration in pharmacy came from that they want to mimic a bit what is happening to the medical schools. Whereas in pharmacy things are not exactly the same" R1

"Our attempts to spiral the learning never took off, nobody has got the time, nobody really wants to do anything new ... but there's probably lots of members of staff who have taught the same thing for years and don't really want to change what they do" R7

"The trouble with the course here is that it is longstanding and people are trying to move bits around, rather than starting with a blank sheet of paper and saying, okay, here is where we are trying to get to, this is the end point, how do we get there? We stuck with the people that are here and the equipment that we've got and attitudes and the memory of how things used to be" R5 